\title{
Using Laboratory Flow Experiments and Reactive Chemical Transport Modeling for Designing Waterflooding of the Agua Fría Reservoir, Poza Rica- Altamira Field, Mexico
}

P. Birkle, Instituto de Investigaciones Eléctricas; K. Pruess, SPE, and T. Xu, Lawrence Berkeley National Laboratory; R.A. Hernández Figueroa, and M. Díaz López, Petróleos Mexicanos; and E. Contreras López, Instituto de Investigaciones Eléctricas

\begin{abstract}
Waterflooding for enhanced oil recovery requires that injected waters must be chemically compatible with connate reservoir waters, in order to avoid mineral dissolution-and-precipitation cycles that could seriously degrade formation permeability and injectivity. Formation plugging is a concern especially in reservoirs with a large content of carbonates, such as calcite and dolomite, as such minerals typically react rapidly with an aqueous phase, and have strongly temperature-dependent solubility. Clay swelling can also pose problems. During a preliminary waterflooding pilot project, the Poza Rica-Altamira oil field, bordering the Gulf coast in the eastern part of Mexico, experienced injectivity loss after five months of reinjection of formation waters into well AF-847 in 1999. Acidizing with $\mathrm{HCl}$ restored injectivity.

We report on laboratory experiments and reactive chemistry modeling studies that were undertaken in preparation for long-term waterflooding at Agua Fría. Using analogous core plugs obtained from the same reservoir interval, laboratory coreflood experiments were conducted to examine sensitivity of mineral dissolution and precipitation effects to water composition. Native reservoir water, chemically altered waters, and distilled water were used, and temporal changes in core permeability, mineral abundances and aqueous concentrations of solutes were monitored. The experiments were simulated with the multi-phase, nonisothermal reactive transport code TOUGHREACT, and reasonable to good agreement was obtained for changes in solute concentrations. Clay swelling caused an additional impact on permability behaviour during coreflood experiments, whereas the modeled permeability depends exclusively on chemical processes. TOUGHREACT was then used for reservoir-scale simulation of injecting ambient-temperature water $\left(30^{\circ} \mathrm{C}\right.$, $\left.86^{\circ} \mathrm{F}\right)$ into a reservoir with initial temperature of $80^{\circ} \mathrm{C}\left(176^{\circ} \mathrm{F}\right)$. Untreated native reservoir water was found to cause serious porosity and permeability reduction due to calcite precipitation, which is promoted by the retrograde solubility of this mineral. Using treated water that performed well in the laboratory flow experiments was found to avoid excessive precipitation, and allowed injection to proceed.
\end{abstract}

\section{Introduction}

The Poza Rica - Altamira oilfield forms part of the Chicontepec region, located in the eastern part of Central Mexico in the State of Veracruz, about five km from the town of Poza Rica and $250 \mathrm{~km}$ NE from Mexico City (Fig. 1). The thick, low-permeable accumulation of Paleocene-age sediments within the Chicontepec paleochannel contains an estimated 139 billion barrels [22 billion $\mathrm{m}^{3}$ ] of original oil in place and 50 Tcf [1.4 Trillion $\mathrm{m}^{3}$ ] of gas $^{1}$. A total of 951 production wells were completed from 1951 to 2002, with initial production rates on the order of 70 to $300 \mathrm{BPD}$ (barrels of oil per day) [11 to $48 \mathrm{~m}^{3} / \mathrm{d}$ ].

Recently, PEMEX initiated an aggressive strategy to increase field production from an average of 2,500

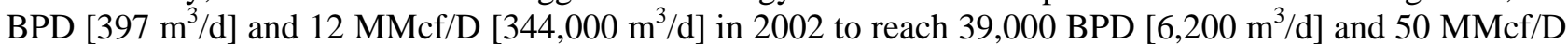
[1.4 million $\mathrm{m}^{3} / \mathrm{d}$ ] in $2006^{2}$. Central to the success is the construction of high productivity wells, as well as waterflooding as part of an enhanced oil recovery program. 


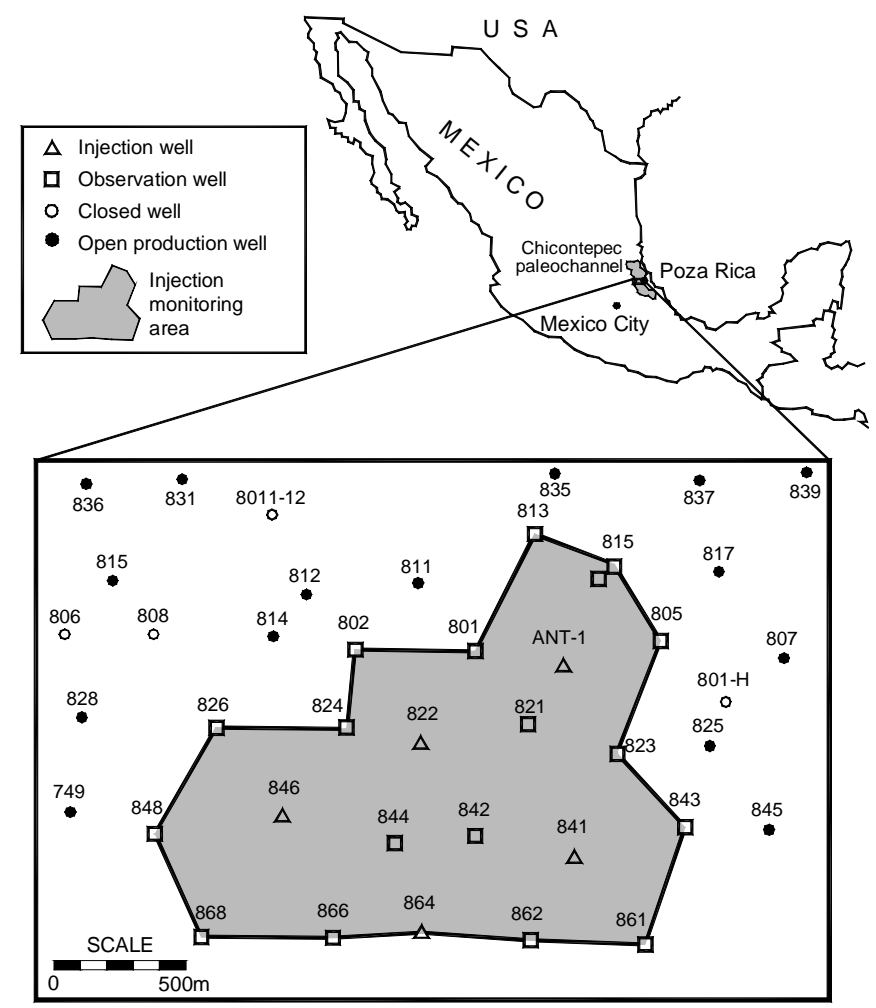

Fig. 1-Location of 5 injection wells and 18 monitoring wells within the Agua Fría field as part the scheduled enhanced oil recovery project at the Poza Rica - Altamira oil field, State of Veracruz.

During a preliminary waterflooding pilot project in 1999, a maximum injection rate of 4,000 BPD was applied to well AF-847. Figure 2 shows the pressure and water injection rate during the initial 5 months of the injection experiment. Increasing injection rates from 240 BPD to 4000 BPD caused a pressure rise from 50 bar to 230 bar, whereby initial pressure conditions were not recovered during intercalated fall-off tests (Q=0 BPD). After 167 days of injection, the well capacity decreased to 1,920 BPD. Acidizing with 15\% $\mathrm{HCl}$ partially restored the primary injectivity of the well, as injection rate increased to 2,500 BPD.

This paper presents selected results from a study undertaken to develop guidelines for an appropriate treatment of reservoir water from the Poza Rica collector station (Central de Almacenamiento y Bombeo Poza Rica) before its injection into the Chicontepec reservoir of the Agua Fría field. Specific issues addressed include the following.

- Define mechanisms and chemical, physical-mechanical and biological processes that may cause plugging of the injection interval.

- Characterize materials causing scale formation in fractures and pores.

- Design a practical treatment procedure for reservoir water for its injection into the oil reservoir.

In general, the design of a treatment process for injection water shall support the waterflooding project of the enhanced oil recovery program, especially to prevent installation damage and reservoir scaling of the Chicontepec reservoir of the Agua Fría field. This paper presents results of laboratory flow experiments at core-scale and numerical simulations with the TOUGHREACT code for chemically reactive flows to reconstruct potential chemical and physical processes during the injection of untreated and treated connate formation water into the Agua Fría oil reservoir. 


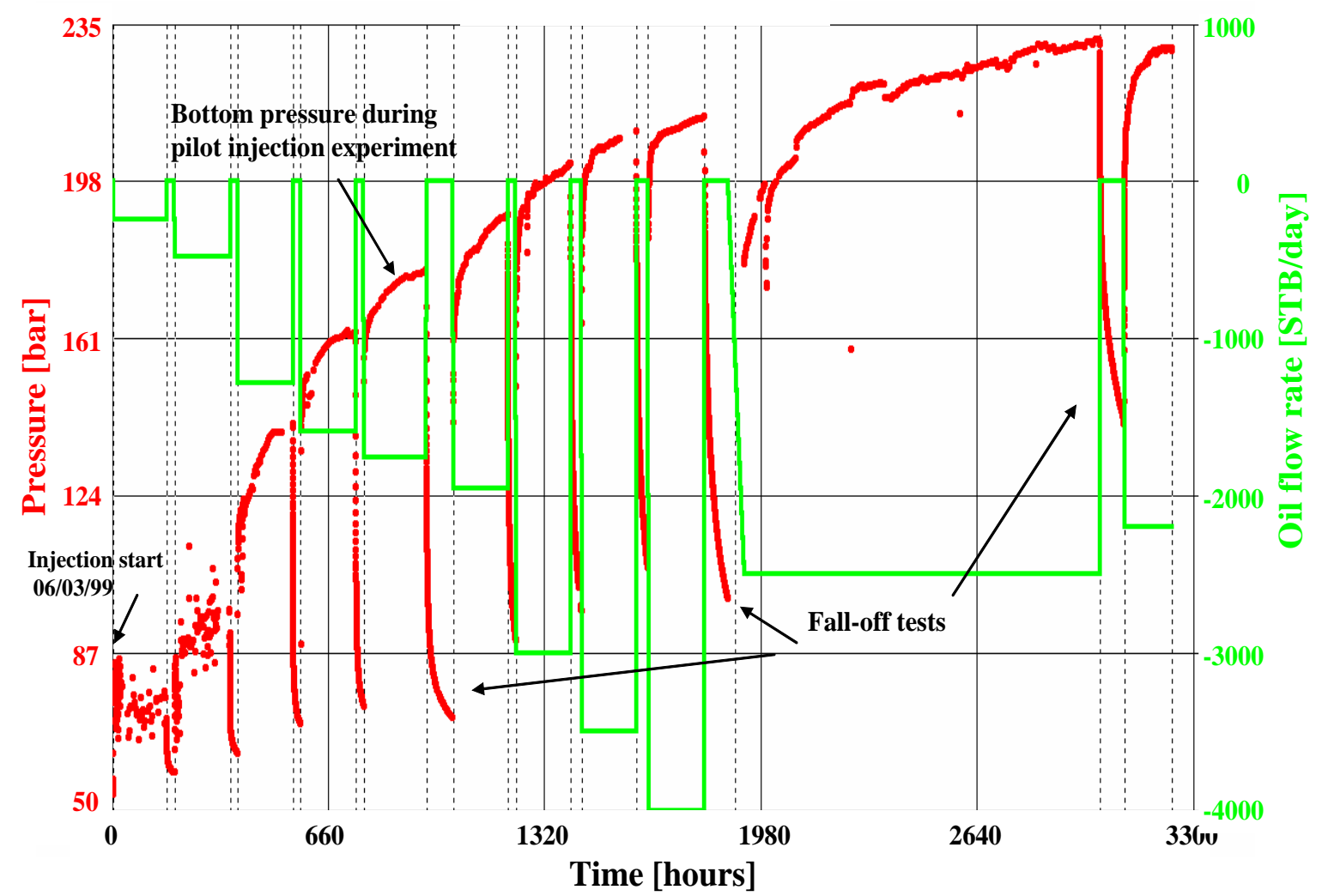

Fig. 2-Applied injection rates and pressure behavior during a waterflooding pilot project in well AF-847.

\section{Methods - Flow experiments}

The laboratory flow experiments were designed to monitor permeability changes (by means of pressure measurements), using a specific fluid with a determined hydrochemical composition under certain pressure and temperature conditions. Observed changes of the core permeability can be attributed to physicalchemical processes, such as pore obstruction by suspended particles, organic material, clay swelling, and precipitation or dissolution of minerals. Besides the continuous monitoring of permeability changes of the core, the comparison of the chemical and mineralogical composition of the fluid and core before and after the flow experiment indicate dissolution and/or precipitation processes.

As no drill cores are available from the proposed injection wells, samples were selected as representative as possible from analogous lithological core sections from adjacent production wells. The density of dry rock, pore volume and effective porosity were determined under surface conditions using techniques recommended by the American Petroleum Institute ${ }^{3}$. The absolute permeability to gas was obtained experimentally using Darcy's law.

Inlet and outlet water samples were stored in HDPE bottles, pre-filtered with $0.45 \mu \mathrm{m}$ Millipore filters, acidified with $\mathrm{HNO}_{3}$-Suprapur, and analyzed for their major, minor and trace element composition. Mineralogical analysis and clay speciation were obtained by X-ray diffraction.

\section{Numerical approaches}

\section{Main features of the model}

The numerical simulation tool TOUGHREACT was developed by introducing reactive chemistry into the framework of the existing multi-phase fluid and heat flow code TOUGH2 ${ }^{4}$. Flow and transport in geologic media are modeled based on space discretization by means of integral finite differences ${ }^{5}$. An implicit timeweighting scheme is used for the individual components of the model consisting of flow, transport, and 
geochemical reaction. The program uses a sequential iteration approach for coupling transport and reaction. Full details on numerical methods are given in Xu and Pruess $(2001)^{6}$ and Xu et al. (2006) ${ }^{7}$.

The TOUGHREACT model can be applied to one-, two-, or three-dimensional porous and fractured media with physical and chemical heterogeneity. The model can accommodate any number of chemical species present in the liquid, gas and solid phases. A wide range of subsurface thermo-physical-chemical processes is considered. Major processes for fluid and heat flow are: (1) fluid flow in both liquid and gas phases occurs under pressure and gravity forces; (2) capillary pressure effects are considered for the liquid phase; and (3) heat flow occurs by conduction, convection and diffusion. Transport of aqueous and gaseous species by advection and molecular diffusion is considered in both liquid and gas phases.

\section{Changes of porosity and permeability}

Laboratory experiments have shown that modest reductions in porosity from mineral precipitation can cause large reductions in permeability ${ }^{8}$. Detailed analysis of a large set of field data also indicates a strong dependence of permeability on small porosity changes ${ }^{9}$. The convergent-divergent nature of pore channels explains the possible plugging of pore throats by precipitation while disconnected void space remain in the pore bodies ${ }^{10}$. To evaluate the effects of a sensitive coupling of permeability to porosity, the following Verma-Pruess equation ${ }^{10}$ was applied for Zone 1 (Distance from injection well: $0 \mathrm{~m}-20 \mathrm{~m}$ ):

$$
\frac{k}{k_{i}}=\left(\frac{\phi-\phi_{c}}{\phi_{i}-\phi_{c}}\right)^{n}
$$

where $\phi_{c}$ is the value of "critical" porosity at which permeability goes to zero, and $n$ is a power law exponent ${ }^{7}$. Parameters $\phi_{c}$ and $n$ are medium-dependent.

For Zone 2 (Distance from injection well: 20 - 200 m), a cubic law was employed.

$$
k=k_{i}\left(\frac{\phi}{\phi_{i}}\right)^{3}
$$

where $k_{i}$ and $\phi_{1}$ represent the initial permeability and porosity, respectively. This law yields zero permeability only under the condition of zero porosity. The Verma-Pruess model for permeability reduction (Eq. 1) is applicable on smaller scales, while on larger scales less severe permeability loss would be expected from porosity reduction. Accordingly, Eq. (1) is used within $20 \mathrm{~m}$ distance from the injection well, while the Kozeny Eq. (2) is used at larger distance ${ }^{11}$.

\section{Results}

\section{Batch-experiments: Calibration of numerical modeling with laboratory coreflood experiments}

In order to assess the realism of numerical simulations with TOUGHREACT for the injection process into the Agua Fría reservoir, data from laboratory flow experiments were compared with numerical results. Both distilled water and formation water were injected into representative reservoir cores on a laboratory scale in order to correlate changes in permeability with possible alterations in rock mineralogy and fluid chemistry.

\section{Distilled water}

\subsection{Core experiments with distilled water}

A Klinkenberg permeability $\left(K_{L}\right)$ of 292 millidarcies and an effective porosity of $12 \%$ were measured for a representative, 1.5" sandstone core from the injection interval ("Cuerpo 70") from the well Coapechaca595 (depth: $1,662.68 \mathrm{~m}$ ) after a previous cleaning process with solvent and drying at $95^{\circ} \mathrm{C}$. As clay mineral structure collapses at much higher temperatures (kaolinite up to $600^{\circ} \mathrm{C}$, chlorite above $600^{\circ} \mathrm{C}$ ) and leads to a slight increase in porosity ${ }^{12}$, the applied drying technique, based on the Norm API RP 40 "Recommended 


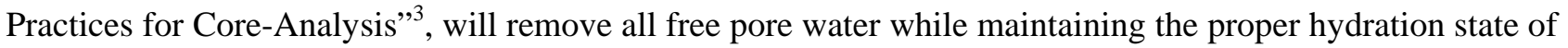
swelling clays. To prepare the core for the following flow experiment, the sample was saturated with distilled water for two days under vacuum and pressurized conditions $\left(100 \mathrm{~kg} / \mathrm{cm}^{2}\right)$, whereby clay swelling caused probably the decrease of the initial permeability from 292 to $60 \mathrm{mD}$. During the subsequent laboratory experiment with distilled water at a flow rate between one $\mathrm{cm}^{3} / \mathrm{min}$ (initial stage) and eight $\mathrm{cm}^{3} / \mathrm{min}$ (final stage) at $25^{\circ} \mathrm{C}$, permeability increased from 60 to $174 \mathrm{mD}$ within a time period of $407 \mathrm{~min}$ $(0.28 \mathrm{~d})$ at a total throughput of 148 pore volumes $(1080 \mathrm{~mL})(\mathbf{F i g} .3)$.

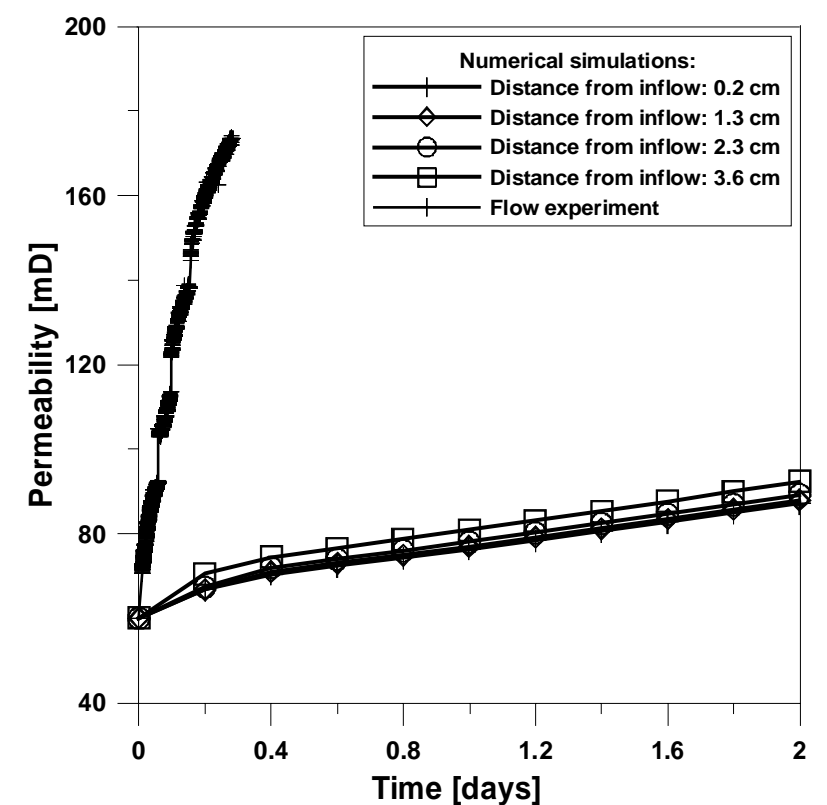

Fig. 3-Comparison of the permeability evolution during core flood experiments with distilled water with numerical results from TOUGHREACT. Numerical values are presented at a distance of $0.2,1.3,2.3$ and $3.6 \mathrm{~cm}$ from the inlet of the core.

A $\mathrm{K}_{\mathrm{L}}$ value of $316 \mathrm{mD}$, measured at the same core after the flow experiment and after drying at $95^{\circ} \mathrm{C}$, confirms a slight increase of the initial Klinkenberg permeability (from 292 to $316 \mathrm{mD}$ ) due to chemical reactions during coreflooding. The increase of solute concentrations in the core outflow, especially in $\mathrm{Ca}^{2+}$, $\mathrm{SO}_{4}{ }^{2-}$ and $\mathrm{HCO}_{3}{ }^{-}$(Column 4 in Table 1) confirms the occurrence of carbonate and sulfate mineral dissolution.

TABLE 1-COMPARISON OF THE CHEMICAL ANALYSIS OF DISTILLED WATER BEFORE AND AFTER THE FLOW EXPERIMENT WITH TOUGHREACT SIMULATION RESULTS (DURATION $=0.28$ DAYS)

\begin{tabular}{|c|c|c|c|c|c|c|}
\hline \multirow[t]{2}{*}{$\begin{array}{l}\text { Aqueous } \\
\text { Species }\end{array}$} & \multicolumn{2}{|c|}{$\begin{array}{l}\text { Distilled water } \\
\text { Inflow }\end{array}$} & \multicolumn{2}{|c|}{$\begin{array}{c}\text { Flow experiment } \\
\text { Outflow }\end{array}$} & \multicolumn{2}{|c|}{$\begin{array}{c}\text { Numerical simulation } \\
\text { Outflow }\end{array}$} \\
\hline & {$[\mathrm{mg} / \mathrm{kg}]$} & [mol/kg] & [mg/kg] & {$[\mathrm{mol} / \mathrm{kg}]$} & [mg/kg] & {$[\mathrm{mol} / \mathrm{kg}]$} \\
\hline $\mathrm{Cl}^{-}$ & 0.63 & 1.777E-05 & 0.78 & $2.200 \mathrm{E}-05$ & 0.63 & 1.777E-05 \\
\hline $\mathrm{HCO}_{3}{ }^{-}$ & 21.0 & 3.442E-04 & 30.0 & 4.917E-04 & 437.6 & 7.174E-03 \\
\hline $\mathrm{SO}_{4}{ }^{2-}$ & 0.05 & 5.205E-07 & 43.4 & $4.518 \mathrm{E}-04$ & 0.10 & $1.000 \mathrm{E}-06$ \\
\hline $\mathrm{Na}^{+}$ & 12.8 & 5.568E-04 & 1.74 & $7.569 \mathrm{E}-05$ & 12.8 & 5.569E-04 \\
\hline $\mathrm{Mg}^{2+}$ & 0.09 & 3.538E-06 & 1.56 & $6.418 \mathrm{E}-05$ & 1.53 & 6.300E-05 \\
\hline $\mathrm{SiO}_{2}$ (aq.) & 0.63 & 1.050E-05 & 1.29 & 2.147E-05 & 0.065 & $1.086 \mathrm{E}-06$ \\
\hline $\mathrm{K}^{+}$ & 0.13 & 3.427E-06 & 0.37 & $9.489 \mathrm{E}-06$ & 0.13 & $3.429 \mathrm{E}-06$ \\
\hline $\mathrm{Ca}^{2+}$ & 0.83 & 2.058E-05 & 25.0 & $6.238 \mathrm{E}-04$ & 105.3 & $2.626 \mathrm{E}-03$ \\
\hline $\mathrm{Sr}^{2+}$ & 0.05 & $5.250 \mathrm{E}-07$ & 0.20 & $2.283 E-06$ & 0.05 & 5.240E-07 \\
\hline$\Gamma$ & 0.34 & $2.640 \mathrm{E}-06$ & 0.011 & 8.668E-08 & 0.33 & 2.639E-06 \\
\hline $\mathrm{Ba}^{2+}$ & 0.016 & 1.187E-07 & 0.015 & 1.107E-07 & 0.016 & 1.180E-07 \\
\hline $\mathrm{Fe}^{2+}$ & 0.010 & $1.791 \mathrm{E}-07$ & 0.065 & $1.164 \mathrm{E}-06$ & 7.84 & $1.405 \mathrm{E}-04$ \\
\hline
\end{tabular}




\subsection{Numerical simulation of the core experiment}

Chemical analytical data from distilled water were applied as input parameters (Column 2 in Table 1). Petrophysical core characteristics are given in Table 2, and the mineralogical composition was taken from the applied core 2 from the well Coapechaca-595 (Table 3). As a result, permeability increases from an initial value of $60 \mathrm{mD}$ to $72 \mathrm{mD}$ in a time period of 0.28 days (407 $\mathrm{min})$. The trend continues linearly to maximum values of $92 \mathrm{mD}$ after 2 days (Fig. 3). Variations of the permeability in respective core sections at different distances from the core inlet are insignificant. The main reason for the increase of the core permeability is the dissolution of host rock minerals (mainly calcite dissolution). A maximum dissolution of $0.015 \%$ of the total rock volume occurs close to the inlet after 0.28 days of simulation, and $0.03 \%$ after 2 days.

TABLE 2-PARAMETERS FOR THE SIMULATION OF COREFLOODING WITH DISTILLED AND RESERVOIR WATER.

\begin{tabular}{l|l|l}
\hline Coreflood case & Injection of destilled water & Injection of reservoir water \\
\hline Number of grid blocks & 10 & 10 \\
Initial porosity & $12.0 \%$ & $14.0 \%$ \\
Critical porosity & $11.3 \%$ & $13.0 \%$ \\
Initial permeability KL & $60 \mathrm{mD}$ & $220 \mathrm{mD}$ \\
Density & $2.265 \mathrm{~g} / \mathrm{cm}^{3}$ & $2.33 \mathrm{~g} / \mathrm{cm}^{3}$ \\
Porosity-permeability correlation & Equation 1 (Verma \& Pruess, 1988) & Equation 1 (Verma \& Pruess, 1988) \\
Length of the core & $36 \mathrm{~mm}$ & $36 \mathrm{~mm}$ \\
Grid spacing & $3.6 \mathrm{~mm}$ & $3.6 \mathrm{~mm}$ \\
Duration of simulation & $0.28 \mathrm{days}$ & $0.6 \mathrm{days}$ \\
Injection rate & $1-8 \mathrm{~cm}^{3} / \mathrm{min}$ & $2 \mathrm{~cm} / 3 / \mathrm{min}(0.333 \mathrm{E}-04 \mathrm{~kg} / \mathrm{s})$ \\
Power law exponent $n$ & 8 & 2 to 8
\end{tabular}

TABLE 3-LIST OF MINERALS CONSIDERED IN THE CORE SCALE SIMULATIONS WITH DISTILLED WATER AND RESERVOIR WATER (MODIFIED VALUES FOR LATTER ONE IN PARENTHESIS).

\begin{tabular}{|c|c|c|c|c|}
\hline Mineral & $\begin{array}{l}\text { Mineral initial } \\
\text { volume fraction }\end{array}$ & $\begin{array}{l}\text { Mineral precipitation/ } \\
\text { dissolution }\end{array}$ & $\begin{array}{l}\text { Activation Energy } \\
{[\mathrm{kJ} / \mathrm{mol}]}\end{array}$ & $\begin{array}{l}\text { Specific surface } \\
\text { area }\left[\mathrm{cm}^{2} / \mathrm{g}\right]\end{array}$ \\
\hline \multicolumn{5}{|l|}{ Primary: } \\
\hline Quartz & $0.33(0.38)$ & Kinetic & 87.7 & 9.8 \\
\hline Calcite & $0.35(0.37)$ & Equilibrium & - & 9.8 \\
\hline Dolomite & $0.07(0.06)$ & Kinetic & 52.2 & 9.8 \\
\hline Albite (low) & $0.04(0.04)$ & Kinetic & 69.8 & 9.8 \\
\hline Ankerite & $0.19(0.13)$ & Kinetic & 62.76 & 9.8 \\
\hline Kaolinite & $0.01(0.01)$ & Kinetic & 22.2 & 151.63 \\
\hline Illite & $0.01(0.01)$ & Kinetic & 35.0 & 151.63 \\
\hline \multicolumn{5}{|l|}{ Secondary: } \\
\hline Calcite $\left(\mathrm{CaCO}_{3}\right)$ & & Equilibrium & - & - \\
\hline Barite $\left(\mathrm{BaSO}_{4}\right)$ & & Equilibrium & - & - \\
\hline Coelestine $\left(\mathrm{SrSO}_{4}\right)$ & & Equilibrium & - & - \\
\hline Strontianite $\left(\mathrm{SrCO}_{3}\right)$ & & Equilibrium & - & - \\
\hline $\mathrm{SiO}_{2}$ (amorph.) & & Kinetic & 60.9 & 9.8 \\
\hline Na-Smecite & & Kinetic & 35.0 & 151.63 \\
\hline Ca-Smectite & & Kinetic & 35.0 & 151.63 \\
\hline
\end{tabular}

\subsection{Comparison of the flow experiment with simulation data}

Both laboratory experiments and numerical simulations resulted in a linear temporal trend of increasing permeability, correlated with decreasing pressure conditions, during coreflooding with distilled water (Fig. 2). Numerical modeling is underestimating the rate of permeability increase observed in the experiment, which suggests that (1) additional physical-chemical processes may operate and (2) parameters used for 
reaction kinetics and porosity-permeability relationship may not accurate. Major support for the occurrence of water-rock interactions during coreflooding derives from an analytical comparison between inlet and outlet fluid composition. The enrichment in $\mathrm{Ca}^{2+}, \mathrm{HCO}_{3}{ }^{-}$and $\mathrm{Fe}^{2+}$ is generally consistent between simulated scenarios and flow experiments. However, concentrations of $\mathrm{Ca}^{2+}, \mathrm{HCO}_{3}^{-}$at the outlet are higher in the simulation than those in the experiment. This is because calcite was specified as equilibrium in the simulation. In fact, calcite dissolution is kinetically-controlled for this experiment scale. Chemical components such as $\mathrm{SO}_{4}{ }^{2-}, \mathrm{Sr}^{2+}, \mathrm{K}^{+}$and $\mathrm{SiO}_{2}$ (aq.) are shown to be chemically reactive during the coreflood experiment. The higher concentrations of $\mathrm{SO}_{4}{ }^{2-}$ and $\mathrm{Sr}^{2+}$ in the experiment may indicate that coelestine $\left(\mathrm{SrSO}_{4}\right)$ is present initially as a primary mineral, but was not specified in the input of the simulation. The higher concentrations of $\mathrm{SiO}_{2}$ (aq.) and $\mathrm{K}^{+}$in the experiment may suggest their bearing minerals present in the primary mineral assemblage.

\section{Reservoir water}

2.1. Core experiments with reservoir water

A representative sandstone core from the injection interval (“Cuerpo 70") from the well Coapechaca-595 at a depth of 1,663.13 m was used for the flow experiment. Based on the norm API RP 40 "Recommended Practices for Core-Analysis" (API 1998), a Klinkenberg permeability of 464 millidarcies to gas and an effective porosity of $14 \%$ were measured for the 1.5 " core, under hydrostatic condition with a stable confining pressure of $56 \mathrm{~kg} / \mathrm{cm}^{2}$ (822.8 psi). The cleaning and saturation process is similar to the previously described coreflood case for distilled water. Clay swelling as a dominant process under static conditions caused significant permeability decrease from 464 to $220 \mathrm{mD}$ over a 3-day saturation period. During the laboratory experiment with reservoir water at $25^{\circ} \mathrm{C}, K_{L}$ decreased from 220 to $78 \mathrm{mD}$ within a short time period of 52 minutes with a flow rate between $2.0 \mathrm{~cm}^{3} / \mathrm{min}$ (initial stage) and $1.5 \mathrm{~cm}^{3} / \mathrm{min}$ (final stage) and a total throughput of 12 pore volumes $(93.1 \mathrm{~mL})$ (Fig. 4). In continuation, experimental conditions were gradually switched to $\mathrm{T}=80^{\circ} \mathrm{C}$ in order to simulate the arrival of tepid water at the heated reservoir. Within a time period of 80 minutes and a flow volume of $80 \mathrm{~mL}, K_{L}$ continued to decrease from 78 to $50 \mathrm{mD}$. Continuing flow at $80^{\circ} \mathrm{C}$ for 310 minutes and a total flow volume of $620 \mathrm{~mL}\left(\mathrm{Q}=1.0 \mathrm{~cm}^{3} / \mathrm{min}_{\mathrm{L}} \mathrm{K}=50->42\right.$ $\mathrm{mD}, \mathrm{Q}=2.0 \mathrm{~cm}^{3} / \mathrm{min} @ \mathrm{~K}_{\mathrm{L}}=40->8 \mathrm{mD}$ ) caused a low-level stabilization around $10 \mathrm{mD}$. Although continuing for additional 480 minutes with a total flow volume of $920 \mathrm{~mL}, K_{L}$ values remained relatively stable between 8 and $10 \mathrm{mD}$. As flow rate has been changed during the coreflood experiment, a direct comparison between pressure behavior and permeability should be made under identical flow rate conditions. Figure $\mathbf{5}$ shows the general increase of $\Delta \mathrm{P}$ with decreasing permeability during the coreflood experiment, e.g from $0.071 \mathrm{~atm}$ (1.04 psi) at $220 \mathrm{mD}$ to $0.131 \mathrm{~atm}(1.92 \mathrm{psi})$ at $118 \mathrm{mD}$ at a constant flow rate Q of $2.0 \mathrm{~cm}^{3} / \mathrm{min}$. 


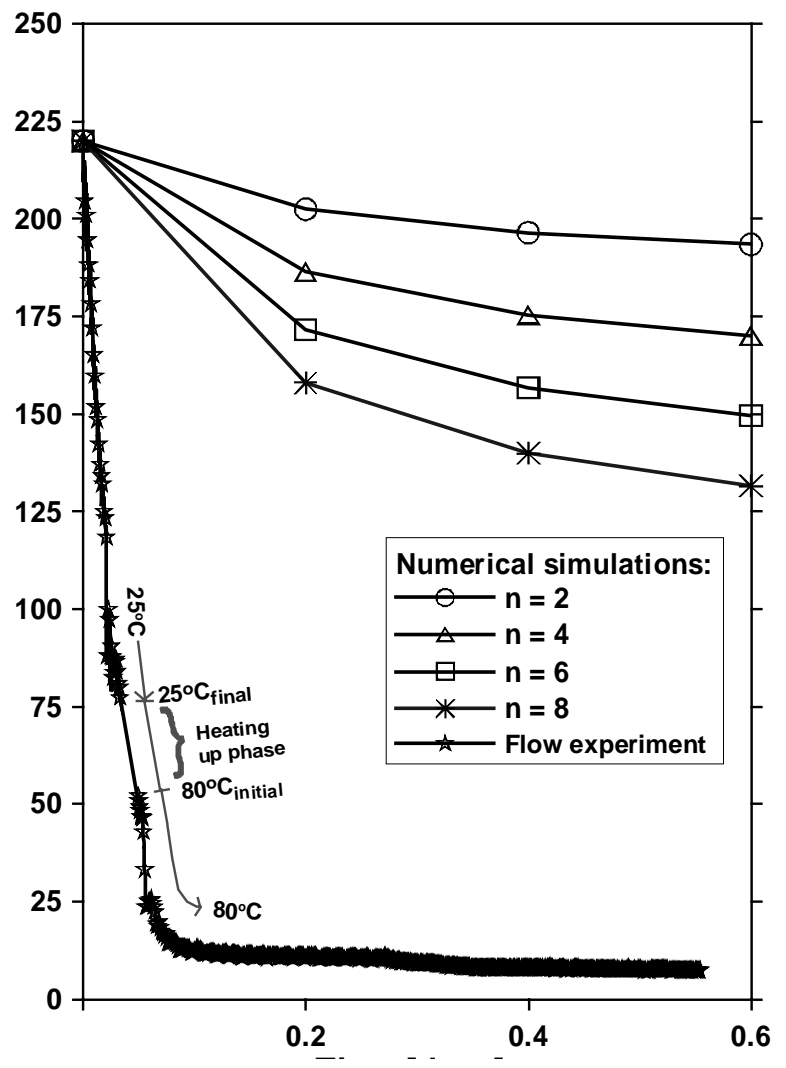

Fig. 4-Comparison of the permeability evolution during coreflood experiments with reservoir water with numerical results from TOUGHREACT. Numerical values are presented at the outlet of the core for different power law exponents $n$ (see Eq. 1).

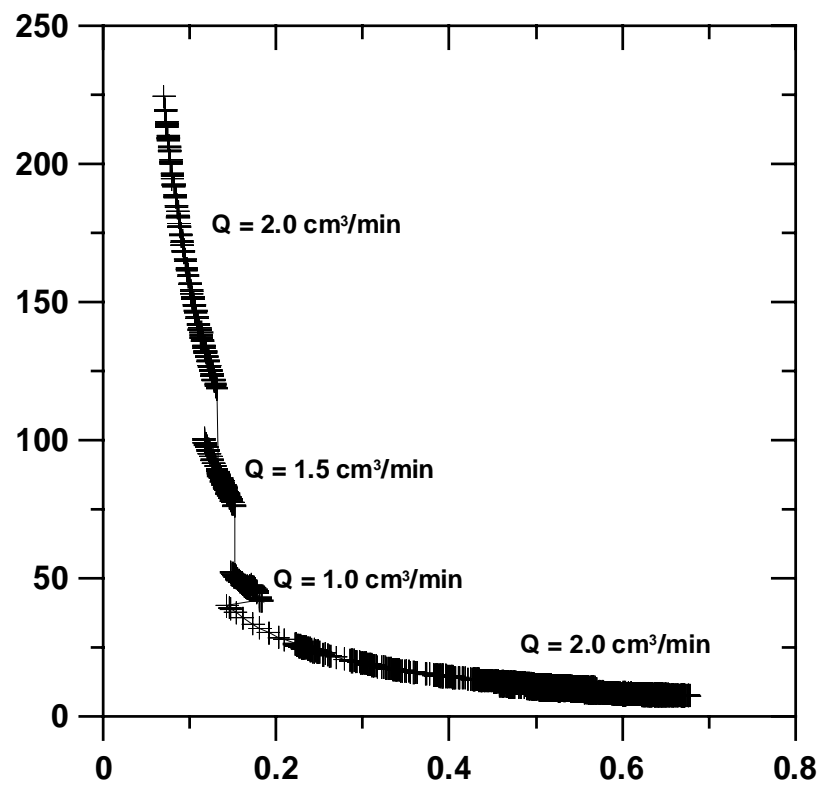

Fig. 5-Correlation between measured pressure difference $\Delta P$ and resulting permeability during the coreflood experiment with reservoir water under different flow rates.

Comparing the mineralogical composition of the core before and after the flow experiment, especially the inlet part of the core presents increasing intensity peaks on the X-ray diffraction diagram, indicating the accumulation of secondary minerals. Figures 6 and 7 show by block-surrounded spaces the net increase between the primary and final composition of individual mineralogical peaks, and grey-filled blocks indicate depleted peaks by probable dissolution processes. 
It is important to mention, that this method yields approximate results due to instrumental and matrix absorption effects. The interpretation of X-ray diffraction diagrams is of semi-quantitative character, as comparison is realized by normalizing the strongest peak to an identical size for each graph. The precipitation of calcite dominates in the inlet part, although the formation of secondary dolomite, ankerite and quartz is also indicated. As a principal observation, the inlet part of the core is dominated by precipitation processes (block-surrounded spaces in Fig. 6), whereas dissolution is dominant in the outlet section (grey-filled blocks in Fig. 7).

The decreasing concentrations of aqueous solutes, especially of $\mathrm{Ca}^{2+}, \mathrm{HCO}_{3}{ }^{-}$and $\mathrm{SO}_{4}{ }^{2-}$ in the outflowing fluid sample in comparison to the original reservoir water composition (Table 4), confirm the precipitation of carbonate and sulfate minerals under oversaturated conditions.

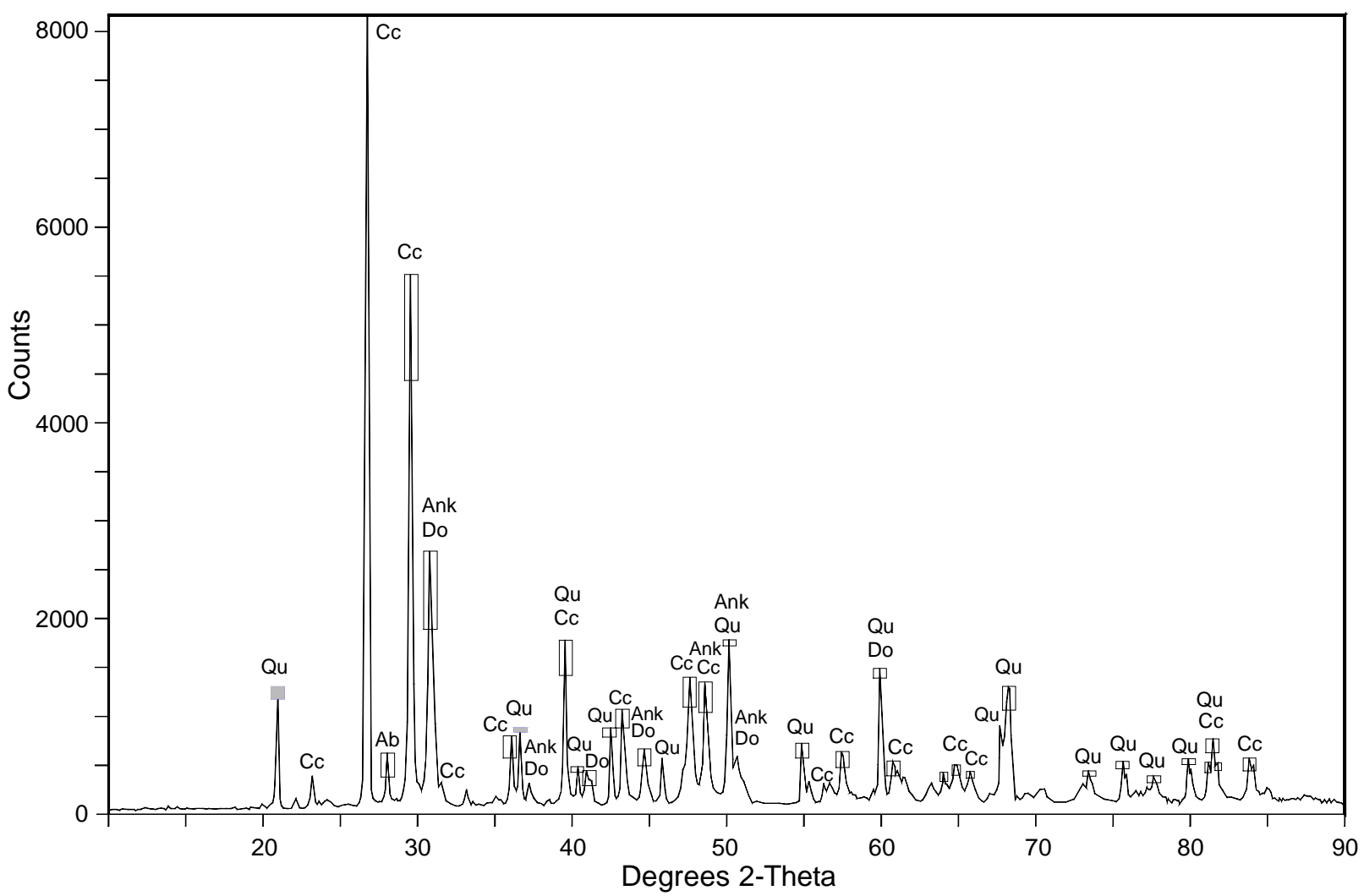

Fig. 6-Change of the mineralogical composition of the core during a flow experiment with reservoir water in the inlet part of the core. Black peaks represent the mineralogical composition after the experiment, block-surrounded spaces reflect the net peak increase during the experiment (probably by precipitation processes), and grey spaces indicate decreasing peaks by probable dissolution processes $(\mathrm{Qu}=\mathrm{quartz}, \mathrm{cc}=\mathrm{calcite}, \mathrm{do}=$ dolomite, $\mathrm{ab}=\mathrm{albite}$, ank=ankerite). 


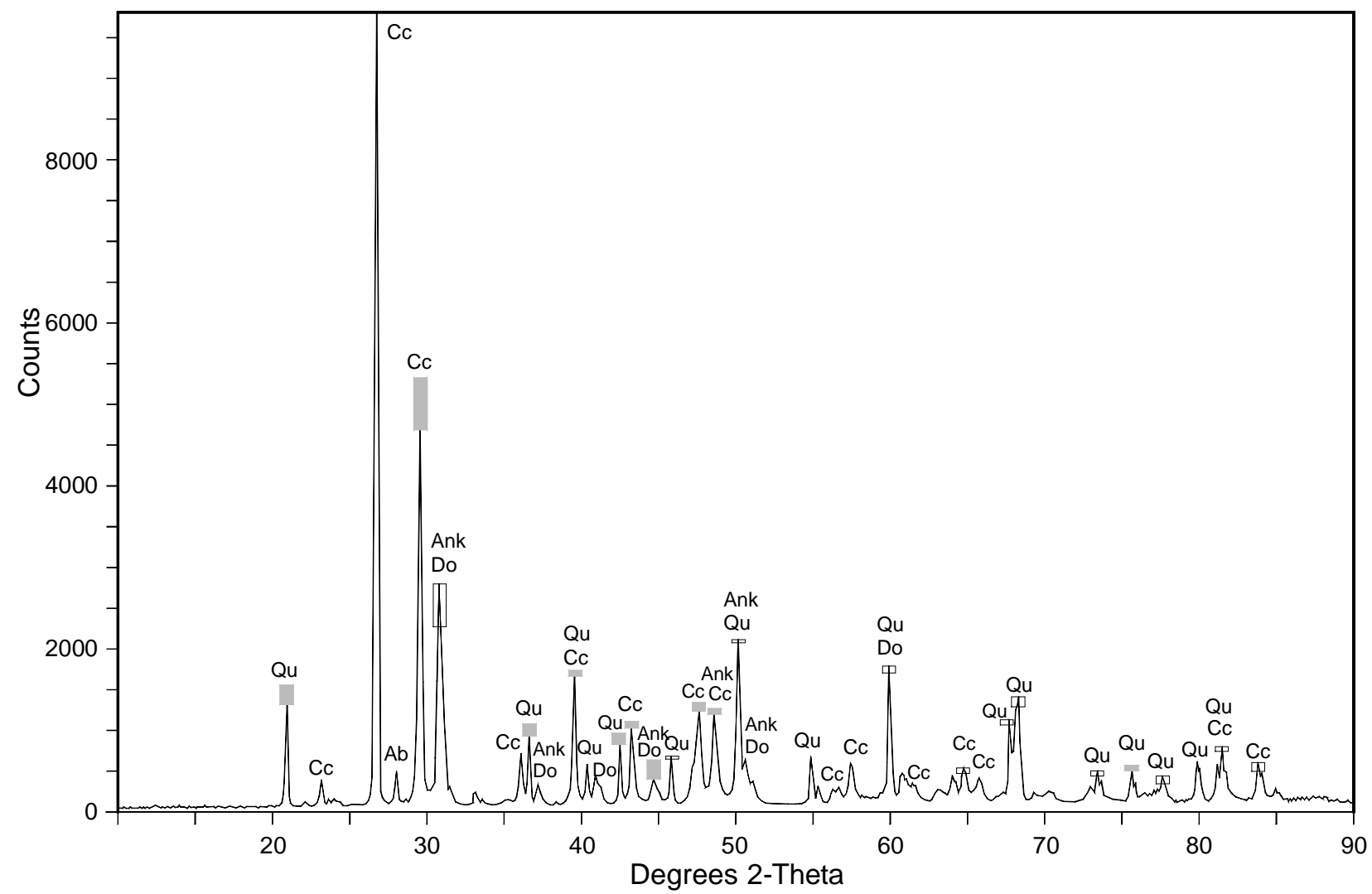

Fig-7. Change of the mineralogical composition of the core during a flow experiment with reservoir water in the outlet part of the core. More description in Figure 6.

TABLE 4-COMPARISON OF THE CHEMICAL ANALYSIS OF RESERVOIR WATER BEFORE AND AFTER THE FLOW EXPERIMENT WITH TOUGHREACT SIMULATION RESULTS (DURATION = 0.6 DAYS)

\begin{tabular}{|c|c|c|c|c|c|c|}
\hline \multirow[t]{2}{*}{$\begin{array}{l}\text { Aqueous } \\
\text { Species }\end{array}$} & \multicolumn{2}{|c|}{$\begin{array}{l}\text { Reservoir water } \\
\text { Inflow }\end{array}$} & \multicolumn{2}{|c|}{$\begin{array}{c}\text { Flow experiment } \\
\text { Outflow }\end{array}$} & \multicolumn{2}{|c|}{$\begin{array}{c}\text { Numerical simulation } \\
\text { Outflow }\end{array}$} \\
\hline & {$[\mathrm{mg} / \mathrm{kg}]$} & [mol/kg] & {$[\mathrm{mg} / \mathrm{kg}]$} & {$[\mathrm{mol} / \mathrm{kg}]$} & {$[\mathrm{mol} / \mathrm{kg}]$} & {$[\mathrm{mol} / \mathrm{kg}]$} \\
\hline $\mathrm{Cl}^{-}$ & 23,373 & 6.593E-01 & 23,494 & 6.627E-01 & 23,371 & $6.59 \mathrm{E}-01$ \\
\hline $\mathrm{HCO}_{3}{ }^{-}$ & 1281.2 & $2.100 \mathrm{E}-02$ & 473.7 & 7.764E-03 & 479.6 & 7.86E-03 \\
\hline $\mathrm{SO}_{4}{ }^{2-}$ & 472.9 & 4.919E-03 & 224.8 & $2.340 \mathrm{E}-03$ & 378.9 & $3.95 \mathrm{E}-03$ \\
\hline $\mathrm{Li}^{+}$ & 11.30 & $1.628 \mathrm{E}-03$ & 11.27 & 1.623E-03 & 11.3 & 1.63E-03 \\
\hline $\mathrm{Na}^{+}$ & 11,254 & 4.895E-01 & 11,169 & 4.858E-01 & 11,251 & $4.89 \mathrm{E}-01$ \\
\hline $\mathrm{Mg}^{2+}$ & 271.2 & 1.116E-02 & 264.8 & 1.089E-02 & 284.4 & 1.17E-02 \\
\hline $\mathrm{SiO}_{2}$ (aq.) & 54.65 & $9.127 \mathrm{E}-04$ & 54.40 & $9.085 \mathrm{E}-04$ & 54.55 & $9.11 \mathrm{E}-04$ \\
\hline $\mathrm{K}^{+}$ & 606.4 & 1.551E-02 & 600.8 & 1.537E-02 & 606.4 & $1.55 \mathrm{E}-02$ \\
\hline $\mathrm{Ca}^{2+}$ & 1082.1 & $2.700 \mathrm{E}-02$ & 819.9 & 2.046E-02 & 846.1 & $2.11 \mathrm{E}-02$ \\
\hline $\mathrm{Sr}^{2+}$ & 84.07 & $9.594 \mathrm{E}-04$ & 80.50 & 9.187E-04 & 0.13 & $1.49 \mathrm{E}-06$ \\
\hline$I^{-}$ & 38.86 & 3.062E-04 & 35.72 & 2.815E-04 & 38.9 & 3.07E-04 \\
\hline $\mathrm{Ba}^{2+}$ & 2.30 & $1.674 \mathrm{E}-05$ & 2.30 & $1.675 \mathrm{E}-05$ & 0.21 & $1.50 \mathrm{E}-06$ \\
\hline $\mathrm{Fe}^{2+}$ & 1.923 & 3.443E-05 & 1.926 & $3.449 \mathrm{E}-05$ & 12.8 & $2.29 \mathrm{E}-04$ \\
\hline
\end{tabular}

\subsection{Numerical simulation of the core experiment}

Chemical analytical data from reservoir water were applied as input data (Table 4), and the mineralogical composition was taken from the applied core 2 from the well Coapechaca-595 (Table 3). Petrophysical parameters for a 1D simulation of the core flood experiment are given in Table 2. The power law exponent $n$ 
from the Verma \& Pruess equation (Eq. 1) was used as calibration parameter in order to simulate different cases. Figure 4 shows the results of four simulations with values for $n$ between two and eight. It is seen that the initial permeability of $220 \mathrm{mD}$ decreases to values between $193.5 \mathrm{mD}(n=2)$ and $131.6 \mathrm{mD}(n=8)$ within 0.6 days (864 min).

As mentioned above, parameters $\phi_{c}$ and $n$ in Eq. 1 are medium-dependent. A fracture with aperture b, has a permeability

$$
k_{i}=b_{i}^{2} / 12 \quad \text { (eq. 3) }
$$

where subscript i denotes values at initial time. Due to mineral precipitation, fracture aperture decreases, or $b<b_{i}$. For porosity $\phi$, we have the relation

$$
\frac{\phi}{\phi_{i}}=\frac{b}{b_{i}}
$$

By combining Eqs. 3 and 4, we have

$$
\frac{k}{k_{i}}=\left(\frac{\phi}{\phi_{i}}\right)^{2}
$$

Therefore, if permeability is dominated by fractures and precipitation occurs uniformly on the fracture surfaces, the parameter $\mathrm{n}$ is 2 . For field-scale media, ideally parameters $\phi_{\mathrm{c}}$ and $\mathrm{n}$ in Eq. 1 should be calibrated from field experiment data, as demonstated in Xu et al. (2004) ${ }^{16}$ who calibrated these two parameters using observed injection indexes to reproduce the loss of injectivity due to silica precipitation. The relationship of Eq. 1 captured very well the steep loss of injectivity, and the simulated amounts of precipitated amorphous silica was consistent with the estimated amounts from field data.

The main reason for the decrease of the core permeability is the precipitation of the secondary minerals calcite $\left(\mathrm{CaCO}_{3}\right)$ and coelestine $\left(\mathrm{SrSO}_{4}\right)$. A maximum calcite precipitation of $0.053 \%$ of the total rock volume occurs at the inflow section of the core after 0.6 days of simulation (Fig. 8).

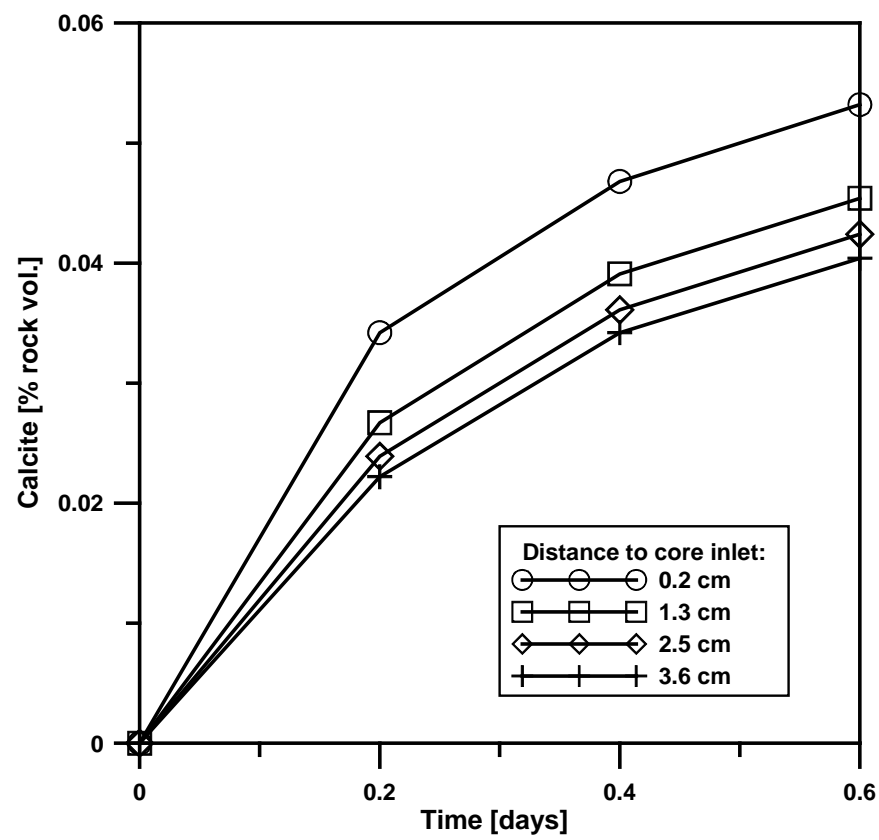

Fig. 8- Numerical simulation of calcite precipitation during a core flood experiment at distances of $0.2,1.3,2.5$ and $3.6 \mathrm{~cm}$ from the core inlet during a time period of 0.6 days.

2.3. Comparison of flow experiment with simulation data 
Measurements of fluid compositions before and after the flow experiment confirm the simulated precipitation of calcite, as pronounced decreases were observed for $\mathrm{HCO}_{3}{ }^{-}$and $\mathrm{Ca}^{2+}$. In addition, the reduction of $\mathrm{SO}_{4}{ }^{2-}$ and $\mathrm{Sr}^{2+}$ concentrations confirm the precipitation of the sulfate mineral coelestine (Table 4). For $\mathrm{HCO}_{3}{ }^{-}$, the simulated decrease from $1281.2 \mathrm{mg} / \mathrm{kg}$ to $479.6 \mathrm{mg} / \mathrm{kg}$ is in excellent agreement with the observed final decline from $1281.2 \mathrm{mg} / \mathrm{kg}$ to $473.7 \mathrm{mg} / \mathrm{kg}$ during the flow experiment (Fig. 9). In general, agreement between simulated and experimental solute concentrations is good overall. However, a slight decrease of $\mathrm{Sr}^{2+}$ concentration in the experiment, but a large decrease of this component in the simulation (Table 4) suggests that coelestine $\left(\mathrm{SrSO}_{4}\right)$ precipitation is kinetically-controlled for this experiment scale rather than equilibrium specified in the simulation. Unchanged $\mathrm{Ba}^{2+}$ concentrations in the experiment, but a large decrease of this component in the simulation (Table 4) suggests that barite $\left(\mathrm{BaSO}_{4}\right)$ precipitation essentially does not occur in the experiment and it should be removed or specified by a very small kinetic rate in the simulation. A very slight increase of $\mathrm{Fe}^{2+}$ concentration in the experiment, but a large increase of this component in the simulation suggests that ankerite adundance may be small in the primary mineral assemblage and/or a small kinetic rate for ankerite dissolution.

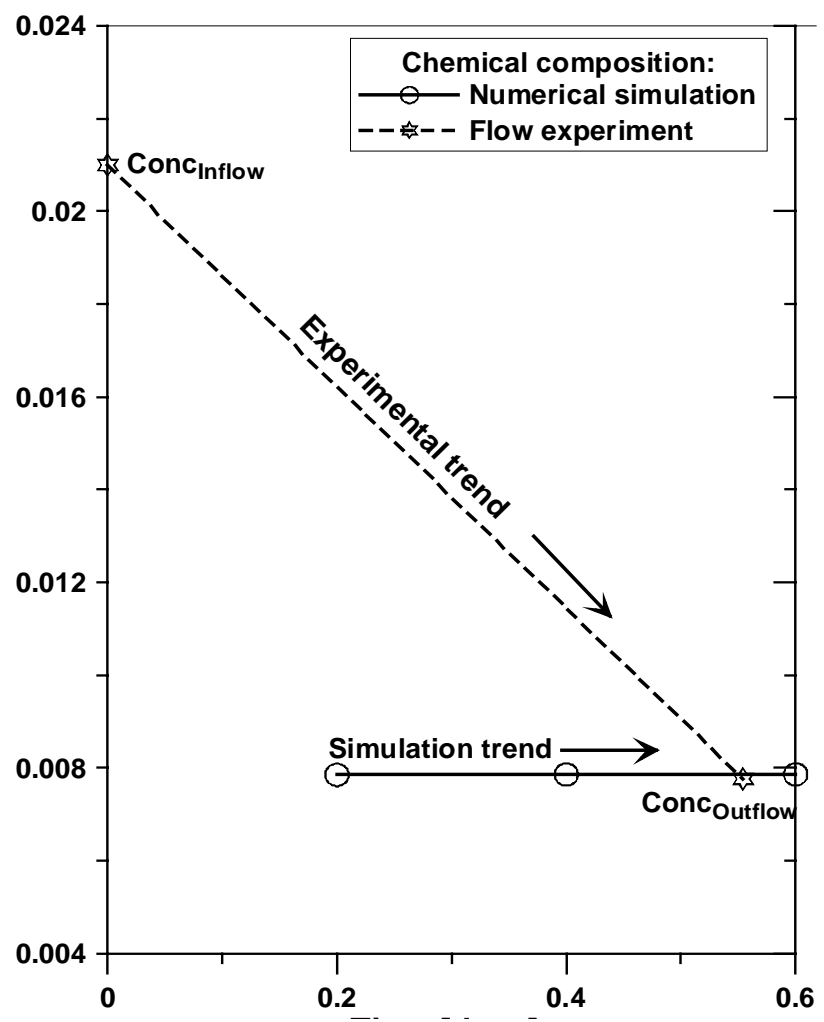

Fig. 9-Comparison of the $\mathrm{HCO}_{3}$ - concentrations before and after the flow experiment with numerical simulations during a period of 0.6 days.

Comparing the permeability decrease in the flow experiment with simulated results, a far more pronounced decrease of the permeability is observed during the laboratory experiment (Fig. 4). The strong decrease of the permeability during the flow experiment is caused by several distinct processes. The decrease under static (no flow) conditions is attributed mainly to clay swelling, whereas under dynamic flow conditions, various processes contribute to permeability reduction, including thermal effects due to heating of the flow system, pore plugging by suspended particles and organic material, and the precipitation of secondary minerals. A separate quantification of the individual processes is extremely difficult. About $20 \%$, which corresponds to the permeability decline from $220 \mathrm{mD}$ to $131.6 \mathrm{mD}$, may be attributed to precipitation of secondary minerals, whereas an estimated $80 \%$ of the permeability reduction may be attributed to clay swelling, confining effects and other processes during static (from 464 to $220 \mathrm{mD}$ ) and dynamic conditions (from 131.6 to $10 \mathrm{mD}$ ). While, numerical simulations with TOUGHREACT consider exclusively mineral dissolution and precipitation. 


\section{Injection of formation water into the oil reservoir}

\section{Problem setup}

\section{Reservoir simulation: Grid and fluid flow parameters}

In the initial stage of an enhanced oil recovery program at the Poza Rica - Altamira oilfield, a total of 16,060 BPD (barrels per day) of formation water from the local fields Coapechaca, Tajín and Agua Fría is planned to be injected into several permeable horizons from five injection wells (AF-822, AF-841, AF-846, AF-864, Antares-1), beginning in 2007. The total thickness of the injection column varies between $138.90 \mathrm{~m}$ (Antares-1) and $317.96 \mathrm{~m}$ (AF-864) at a depth between 1,317 m.b.s.l. and 1,554 m.b.s.l. Fig. 10 shows a 2-D profile of the lithological column and statigraphic correlation between the three injection wells AF-846, AF822 and Antares-1. The subunits 80, 85, 90 and 100 (“Cuerpos”) represent sandstone horizons as potential injection intervals (Table 5) separated by low to impermeable clay-rich units. Several geophysical borehole log methods (GR-gamma ray, RIL-induction log, DIL-deep induction log, SFL-spherical focused log, NCresistivity) and seismic reflection have been applied in order to distinguish fracture zones, porosity characteristics and clay content of the reservoir section, as shown on lateral sides of the lithological columns in Figure 9.

In order to explore possible chemical reactions during the injection process, the $50 \mathrm{~m}$ thick "Cuerpo 90" of the well AF-846 with a planned injection rate of 821 BPD [1.51 kg/s] was selected as prototype for a onelayer numerical model.

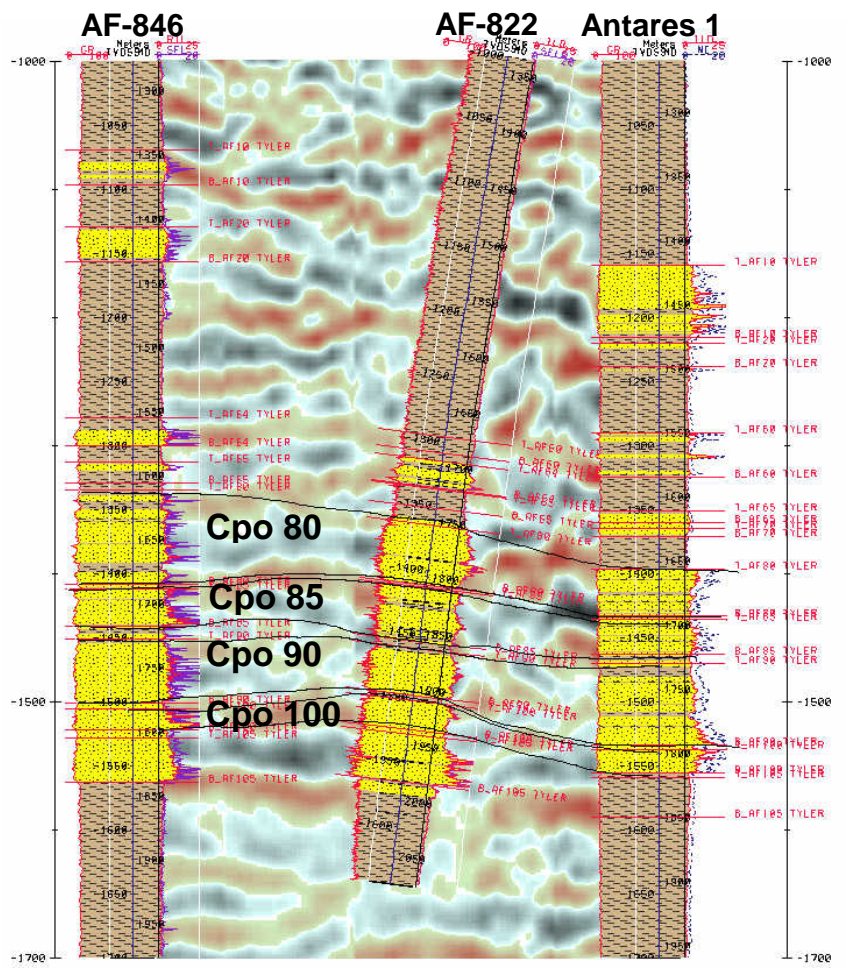

Fig. 10-Lithological communication between the subunits ("Cuerpos 80, 85, 90, 100") of the injection wells AF-846, AF-822 and Antares-1. Also shown are different well log results, such as gamma ray ("GR [API]": red line on the left side of each well column), spherical focused log ("SFL [ohm.m]" in violet color on right side of AF-846 and AF-822), deep resistivity ("ILD [ohm.m]" as red line on right side of AF-88 and Antares-1), resistivity ("NC [ohm.m]" in blue color on left side of well Antares1) and induction logs ("RIL" in red color on right side of well AF-846). In between the lithological column, negative amplitude values $(-128-0)$ of less compact layers are indicated by reddish areas as part of the interpreted seismic reflection, and positive amplitude values $(0-128)$ with blackish shades suggest more compact units. 
TABLE 5-PLANNED INJECTION RATES FOR THE INJECTION WELLS AF-822, AF-841, AF-846, AF-863 AND ANTARES-1 AND THEIR RESPECTIVE SUBUNITS 65, 80, 85, 90, 100 AND 105.

\begin{tabular}{|l|l|l|l|l|l|l|l|}
\hline Well & \multicolumn{7}{|c|}{ Subunits - Injection rate [BPD] } \\
\hline & 65 & 80 & 85 & 90 & 100 & 105 & Total \\
\hline AF-822 & - & 1,142 & 887 & 568 & 558 & 566 & 3,721 \\
\hline AF-841 & - & 1,431 & 540 & 193 & - & 809 & 2,973 \\
\hline AF-846 & - & 1,174 & 726 & 821 & 465 & 516 & 3,702 \\
\hline AF-864 & 33 & 1,290 & 819 & - & 541 & 537 & 3,220 \\
\hline ANT1 & - & 794 & 626 & 888 & 136 & - & 2,444 \\
\hline Total & 33 & 5,831 & 3,598 & 2,470 & 1,700 & 2,428 & 16,060 \\
\hline
\end{tabular}

The 1-D-layer was divided into 80 grid blocks, with 30 blocks from 0 to $20 \mathrm{~m}$ from the injection well, 30 blocks from 20 to $200 \mathrm{~m}$, and 20 blocks from 200 to 5,000 m (Fig. 11). Initial reservoir temperature and pressure were taken as average values of $80{ }^{\circ} \mathrm{C}$ and 240 bar from actual PT-data at the injection interval. A constant injection temperature of $30^{\circ} \mathrm{C}$ was assumed.

The uncertainty of field conditions was addressed by a sensitivity study for reservoir permeability and porosity. The application of the TIXIER equation ${ }^{13}$ on petrophysical logs from the Agua Fría injection wells resulted in reservoir permeabilities $\left(K_{L}\right)$ between $0.1 \mathrm{mD}$ and $10 \mathrm{mD}$ as in the representative case of Figure 10, whereas laboratory flow experiments with dry cores resulted in Klinkenberg permeability values between $0.009 \mathrm{mD}$ and $620 \mathrm{mD}^{14}$. Additionally, the common application of artificial fracturing during the initial stage of well conditioning could increase considerably the low natural permeability of the reservoir in the vicinity of the injection wells.

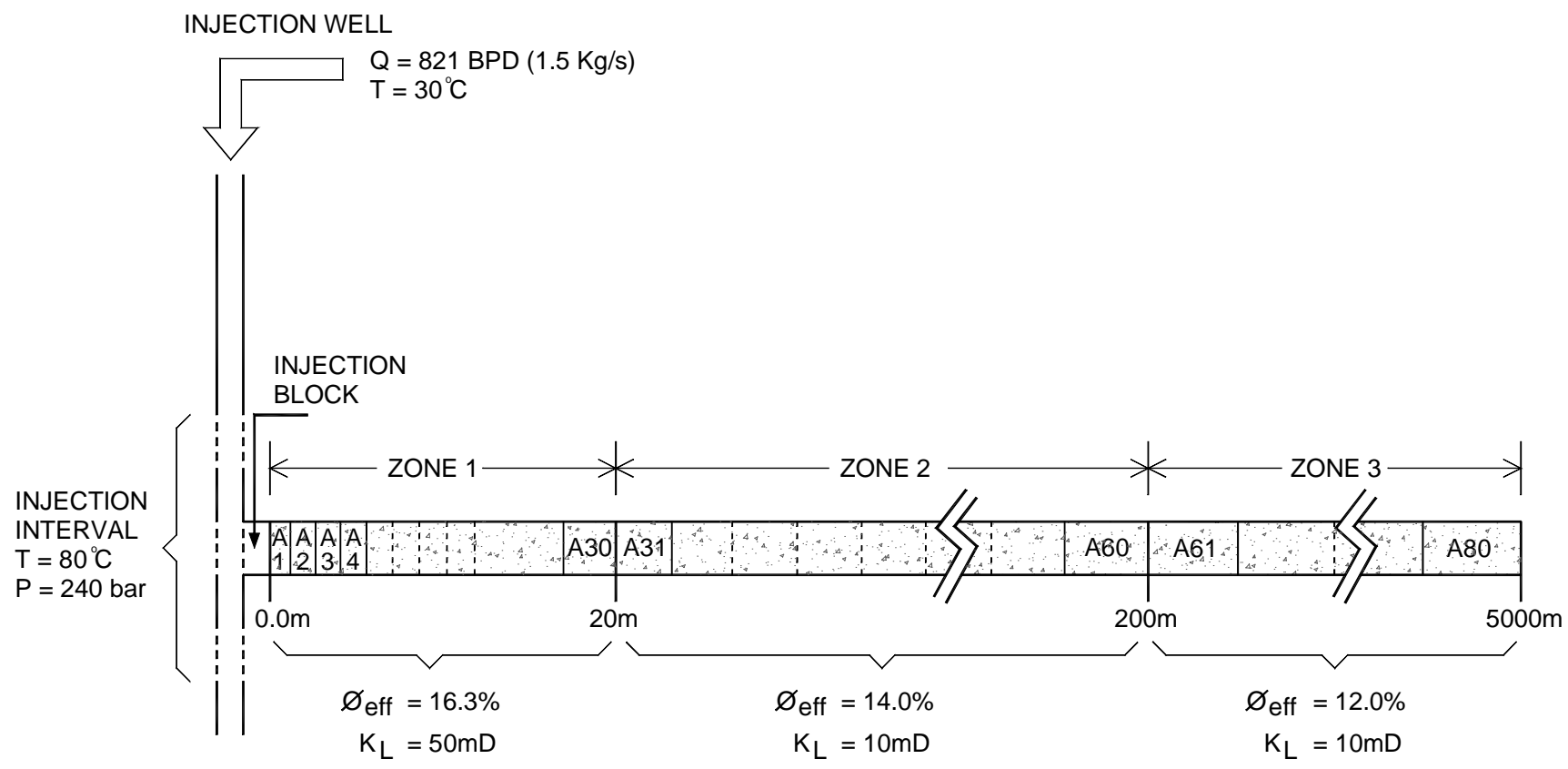

Fig. 11-One-layer grid model and selected petrophysical input parameters for the numerical simulation of the injection of formation water into the Agua Fría reservoir (Case 1).

Effective porosity $\left(\phi_{e f f}\right)$ values between $1.6 \%$ and $16.3 \%$, measured from 83 cores of the Agua Fría and Coapechaca wells reflect the heterogeneous petrophysical conditions of the reservoir ${ }^{14}$. In order to evaluate a possible range of conditions, a reference case with parameters considered most representative (Case 1: $K_{L}=$ $50 \mathrm{mD}, \phi_{\text {eff }}=16.3 \%$ ) is discussed and compared with an optimistic case (Case 2: $\left.K_{L}=500 \mathrm{mD}, \phi_{\text {eff }}=16.3 \%\right)$, and a more pessimistic "worst" case (Case $3: K_{L}=5.0 \mathrm{mD}, \phi_{e f f}=12.0 \%$ ) (Table 6). Complete plugging of 
the reservoir is defined as the case, when critical porosity is reached (eq. 1) at which permeability goes to zero, and injection pressure exceeds original reservoir pressure (240 bar) by 60 bar.

TABLE 6-INPUT PARAMETERS FOR DIFFERENT CASES STUDIES.

\begin{tabular}{|c|c|c|c|}
\hline Parameter & $\begin{array}{l}\text { Case 1: } \\
\text { Reference case }\end{array}$ & $\begin{array}{l}\text { Case 2: } \\
\text { Optimistic case }\end{array}$ & $\begin{array}{l}\text { Case 3: } \\
\text { Worst case }\end{array}$ \\
\hline \multicolumn{4}{|c|}{ Zone 1 (Lateral distance from well: $0.0-20.0 \mathrm{~m}$ ): } \\
\hline$K_{L}$ & $50.0 \mathrm{mD}$ & $500.0 \mathrm{mD}$ & $5.0 \mathrm{mD}$ \\
\hline$\phi_{\text {eff }}$ & $16.3 \%$ & $16.3 \%$ & $12.0 \%$ \\
\hline \multicolumn{4}{|c|}{ Zone 2 (Lateral distance from well: $20.0-200.0 \mathrm{~m}$ ): } \\
\hline$K_{L}$ & $10.0 \mathrm{mD}$ & $100.0 \mathrm{mD}$ & $5.0 \mathrm{mD}$ \\
\hline$\phi_{\text {eff }}$ & $14.0 \%$ & $14.0 \%$ & $10.0 \%$ \\
\hline \multicolumn{4}{|c|}{ Zone 3 (Lateral distance from well: $200.0-5000.0 \mathrm{~m}$ ): } \\
\hline$K L$ & $10.0 \mathrm{mD}$ & $100.0 \mathrm{mD}$ & $5.0 \mathrm{mD}$ \\
\hline$\phi e f f$ & $14.0 \%$ & $14.0 \%$ & $10.0 \%$ \\
\hline
\end{tabular}

\section{Geochemical data}

Homogeneous, detritic lithoarenites with optimum Klinkenberg permeability (620 millidarcy) and effective porosity values (16.3\%) were chosen as representative rock types for the injection interval. The type and initial abundance of primary minerals of the reservoir were taken from mineralogical analysis from Cuerpo 90 (Core 3) at a depth of $1753.72 \mathrm{~m}$ from well Coapechaca-595. The abundance of 2 to $4 \%$ of clay minerals, mainly kaolinite and illite, determined semi-quantitatively by X-ray diffraction, was specified for a total of $100 \%$ (Table 7). Carbonate and sulfate minerals were assumed to react at local equilibrium because their reaction kinetics is typically quite rapid. Other minerals were set to react under kinetic constraints. Thermodynamic data were mainly taken from the EQ3/6 database ${ }^{15}$, and kinetic data were from $\mathrm{Xu}$ et al. (2006) ${ }^{7}$. The kinetic constraints for all minerals, except dolomite with precipitation preferences, were set to allow precipitation and/or dissolution. The activation energies and surface areas for the kinetic minerals are also given in Table 7.

The chemical composition of the injected brine was specified from analytical data from representative field samples, taken from the collector station Central de Almacenamiento y Bombeo (CAB) Poza Rica in March 2005. Column 2 and 3 in Table 4 show the concentration of the primary aqueous components of formation water considered for injection.

Based on the aqueous species present, a total of 40 aqueous complexes were selected from the TOUGHREACT thermodynamic database as having a potential to be formed during injection (Table 8). 
TABLE 7-LIST OF MINERALS CONSIDERED IN THE SIMULATIONS.

\begin{tabular}{|c|c|c|c|c|}
\hline Mineral & $\begin{array}{l}\text { Mineral initial } \\
\text { volume fraction }\end{array}$ & $\begin{array}{l}\text { Mineral precipitation/ } \\
\text { dissolution }\end{array}$ & $\begin{array}{l}\text { Activation } \\
\text { Energy }[\mathrm{kJ} / \mathrm{mol}]\end{array}$ & $\begin{array}{l}\text { Specific surface } \\
\text { area }\left[\mathrm{cm}^{2} / \mathrm{g}\right]\end{array}$ \\
\hline \multicolumn{5}{|l|}{ Primary } \\
\hline Quartz & 0.39 & Kinetic & 87.7 & 9.8 \\
\hline Calcite & 0.30 & Equilibrium & - & 9.8 \\
\hline Dolomite & 0.06 & Kinetic & 52.2 & 9.8 \\
\hline Oligoclase & 0.12 & Kinetic & 69.8 & 9.8 \\
\hline Ankerite & 0.08 & Kinetic & 62.76 & 9.8 \\
\hline Muscovite & 0.01 & Kinetic & 69.8 & 9.8 \\
\hline Kaolinite & 0.02 & Kinetic & 22.2 & 151.63 \\
\hline Illite & 0.02 & Kinetic & 35.0 & 151.63 \\
\hline \multicolumn{5}{|l|}{ Secondary } \\
\hline Calcite $\left(\mathrm{CaCO}_{3}\right)$ & & Equilibrium & - & - \\
\hline Barite $\left(\mathrm{BaSO}_{4}\right)$ & & Equilibrium & - & - \\
\hline Coelestine $\left(\mathrm{SrSO}_{4}\right)$ & & Equilibrium & - & - \\
\hline Strontianite $\left(\mathrm{SrCO}_{3}\right)$ & & Equilibrium & - & - \\
\hline $\mathrm{SiO}_{2}$ (amorph.) & & Kinetic & 60.9 & 9.8 \\
\hline Na-Smecite & & Kinetic & 35.0 & 151.63 \\
\hline Ca-Smectite & & Kinetic & 35.0 & 151.63 \\
\hline
\end{tabular}

TABLE 8-LIST OF SELECTED AQUEOUS COMPLEXES TO FORM POTENTIAL PRODUCTS OF THE INJECTION PROCESS.

\begin{tabular}{|c|c|c|}
\hline $\begin{array}{l}\text { Aqueous } \\
\text { complexes }\end{array}$ & $\begin{array}{l}\text { Aqueous } \\
\text { complexes }\end{array}$ & $\begin{array}{l}\text { Aqueous } \\
\text { complexes }\end{array}$ \\
\hline $\mathrm{OH}^{-}$ & $\mathrm{NaOH}(\mathrm{aq})$ & $\mathrm{NaHCO}_{3}(\mathrm{aq})$ \\
\hline $\mathrm{HAlO}_{2}(\mathrm{aq})$ & $\mathrm{H}_{3} \mathrm{SiO}_{4}^{-}$ & $\mathrm{MgHCO}_{3}^{+}$ \\
\hline $\mathrm{AlOH}^{+2}$ & $\mathrm{Fe}(\mathrm{OH})_{2}(\mathrm{aq})$ & $\mathrm{CO}_{3}{ }^{2-}$ \\
\hline $\mathrm{Al}(\mathrm{OH})_{3}(\mathrm{aq})$ & $\mathrm{H}_{2} \mathrm{~S}(\mathrm{aq})$ & $\mathrm{KCl}(\mathrm{aq})$ \\
\hline $\mathrm{CaCl}_{2}(\mathrm{aq})$ & $\mathrm{H}_{2}(\mathrm{aq})$ & $\mathrm{MgSO}_{4}(\mathrm{aq})$ \\
\hline $\mathrm{NaCl}(\mathrm{aq})$ & $\mathrm{SO}_{2}(\mathrm{aq})$ & $\mathrm{KSO}_{4}^{-}$ \\
\hline $\mathrm{FeHCO}_{3}{ }^{+}$ & $\mathrm{Al}^{3+}$ & $\mathrm{CaOH}^{+}$ \\
\hline $\mathrm{FeCl}_{4}^{2-}$ & $\mathrm{NaAlO}_{2}(\mathrm{aq})$ & $\mathrm{NaCO}_{3}^{-}$ \\
\hline $\mathrm{CaHCO}_{3}^{+}$ & $\mathrm{Al}(\mathrm{OH})_{2}^{+}$ & $\mathrm{Fe}^{3+}$ \\
\hline $\mathrm{CO}_{2}(\mathrm{aq})$ & $\mathrm{CaCl}^{+}$ & $\mathrm{HS}^{-}$ \\
\hline $\mathrm{CaCO}_{3}(\mathrm{aq})$ & $\mathrm{CaSO}_{4}(\mathrm{aq})$ & $\mathrm{CH}_{4}(\mathrm{aq})$ \\
\hline $\mathrm{MgCl}^{+}$ & $\mathrm{FeCl}^{+}$ & Acetic acid (aq) \\
\hline $\mathrm{NaSO}_{4}^{-}$ & $\mathrm{FeCO}_{3}(\mathrm{aq})$ & $\mathrm{HSO}_{3}^{-}$ \\
\hline $\mathrm{NaHSiO}_{3}(\mathrm{aq})$ & & \\
\hline
\end{tabular}

\section{Case 1 (Reference case):}

Assuming an initial $\mathrm{K}_{\mathrm{L}}$ value of 50 millidarcies $(\mathrm{mD})$ and elevated $\phi_{\text {eff }}$ of $16.3 \%$, the injection of untreated native reservoir water is found to cause plugging of the reservoir after 130 days. During this time period, the initial reservoir pressure of 240 bar increased to 296.2 bar close to the well screen, inhibiting the further injection of fluids (Fig. 12a). A relatively small decrease of the effective porosity from $16.3 \%$ to 13.5\% (Fig. 12b) causes a strong drop of the permeability from $50 \mathrm{mD}$ to $0.93 \mathrm{mD}$ (Fig. 13). Chemical reactions affect the reservoir permeability exclusively to a distance of $2.5 \mathrm{~m}$ from the injector well, whereas the original permeability of $50 \mathrm{mD}$ and $10 \mathrm{mD}$ at a distance of $10.1 \mathrm{~m}$ and $52.0 \mathrm{~m}$, respectively, remains unchanged.

The strong decrease of the injectivity of the host formation is due to the continuing precipitation of secondary minerals, mainly calcite $\left(\mathrm{CaCO}_{3}\right)$ (Fig. 14a) and coelestine $\left(\mathrm{SrSO}_{4}\right)$, which is promoted by the retrograde solubility of these minerals. After 130 days, a maximum of $2.24 \%$ and $0.85 \%$ of the total formation volume around the injection well is filled by secondary calcite and coelestine. Simultaneously, a 
minor amount of $0.27 \%$ of the total formation volume of the mineral ankerite [Ca(Fe, $\mathrm{Mg}, \mathrm{Mn}) \mathrm{C}_{2} \mathrm{O}_{6}$ ], has been dissolved $20 \mathrm{~cm}$ from the well screen, but this effect is superimposed on generally oversaturated conditions (Fig. 14b). Other minerals are non-reactive, or with negligible impact on the hydraulic behavior of the formation.

Changes of the mineralogy due to water-rock interaction processes should also be reflected in variations of the fluid composition. As calcite and coelestine represent the principal precipitating minerals, their aqueous components $\mathrm{HCO}_{3}{ }^{-}, \mathrm{Ca}^{2+}, \mathrm{Sr}^{2+}$ and $\mathrm{SO}_{4}{ }^{2-}$ are expected to decrease in concentration during injection. The kinetic rate of calcite is fast, therefore the input concentrations of the model re-equilibrate instantaneously at the beginning of simulation. Calcite precipitation causes a decrease of $\mathrm{Ca}^{2+}$ from $3.1 \times 10^{-2}$ $\mathrm{mol} / \mathrm{kg}$ to a stable concentration of $2.7 \times 10^{-2} \mathrm{~mol} / \mathrm{kg}$ close to the well screen. Lower temperatures close to the injection well, caused by the $30{ }^{\circ} \mathrm{C}$-temperature injection plume, allow a higher solubility for calcite and higher concentrations for $\mathrm{HCO}_{3}{ }^{-}$and $\mathrm{Ca}^{2+}$ than in zones with original reservoir temperatures of $80{ }^{\circ} \mathrm{C}$. The increase of their concentrations at a distance of $10 \mathrm{~m}$ is due to a moving temperature front, while hydrochemical conditions remain stable at a distance of $50 \mathrm{~m}$ because of a constant temperature of $80^{\circ} \mathrm{C}$ (Fig. 15a). The propagation of the temperature front (Fig. 16) from the injection well into the formation is gradually cooling the reservoir, increasing concentrations of $\mathrm{HCO}_{3}{ }^{-}$and $\mathrm{Ca}^{2+}$ (Fig. 15b) due to increasing calcite solubility.

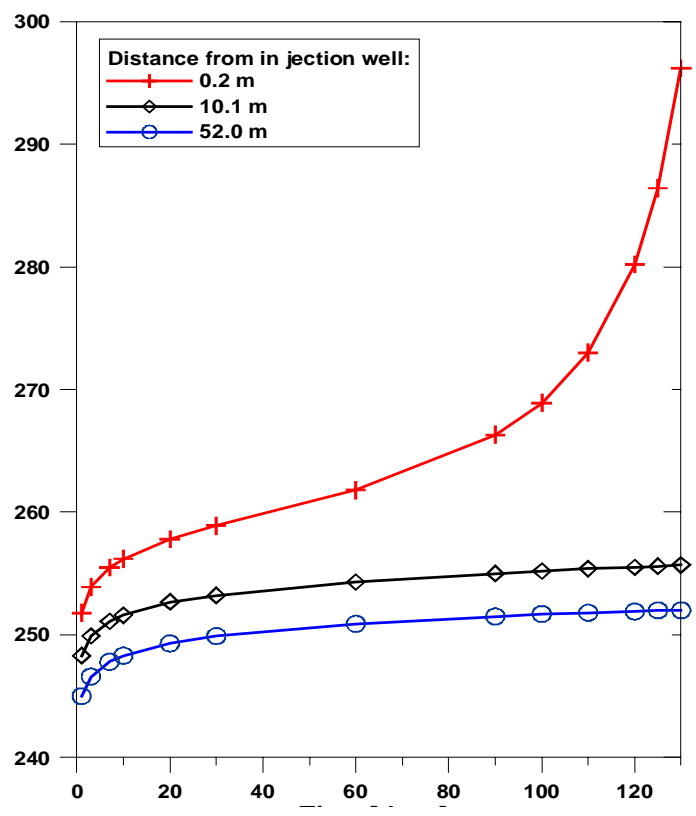

(a)

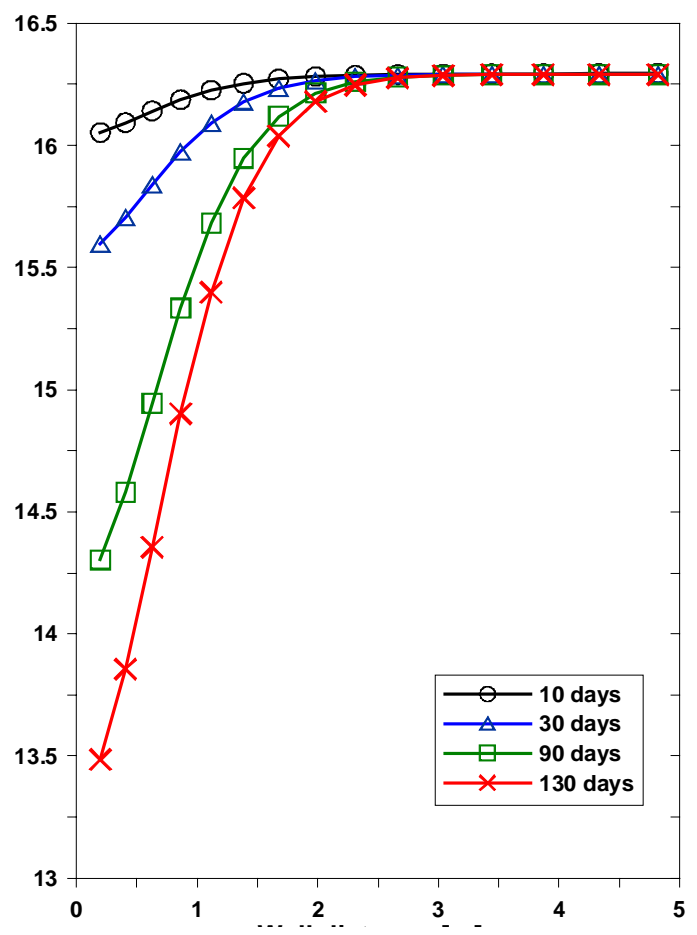

(b)

Fig. 12-Variation of the reservoir pressure at a distance of $0.2 \mathrm{~m}, 10.1 \mathrm{~m}$ and $52.0 \mathrm{~m}$ from the injector well (Fig. 12a). Changes of the primary porosity at different times $(10,30,90,130$ days) to a distance of $5 \mathrm{~m}$ from the injector well (Fig. 12b). 


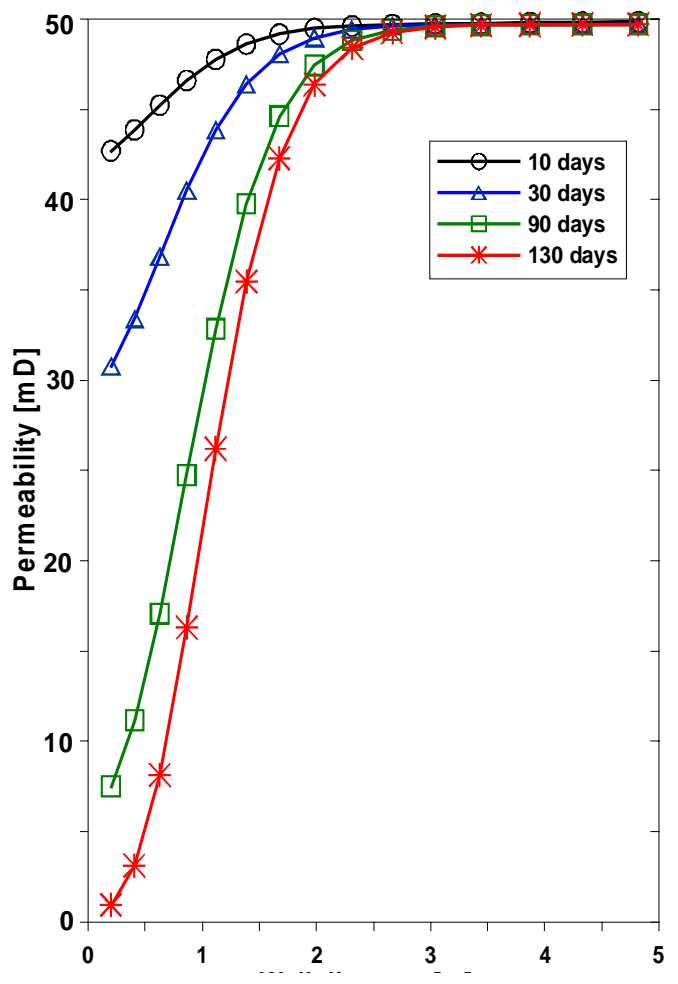

Fig. 13-Permeability changes during the injection of untreated reservoir water at different times (10, 30, 90, 130 days) to a distance of $5 \mathrm{~m}$ from the injector well.

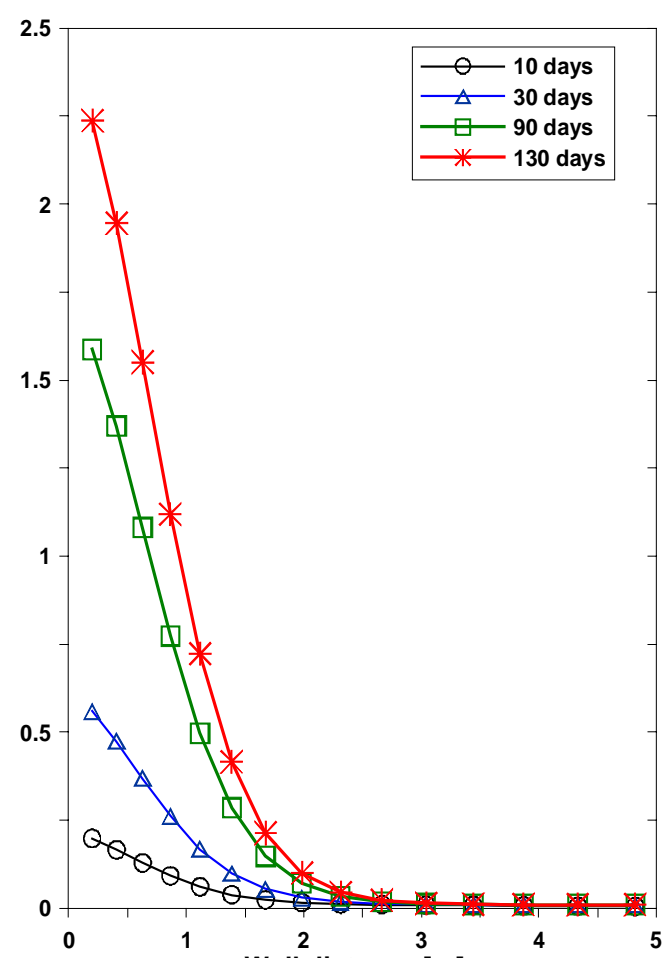

(a)

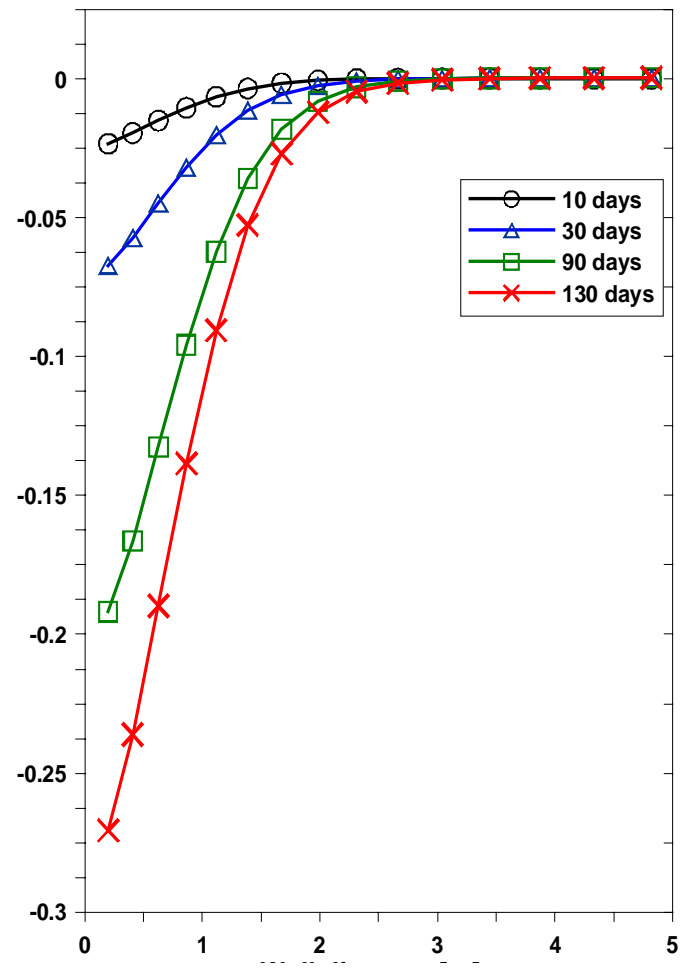

(b)

Fig. 14-Numerical simulation of the accumulation of precipitated calcite (Fig. 14a) and dissolution of ankerite (Fig. 14b) during different times $(10,30,90,130$ days) to a distance of $5 \mathrm{~m}$ from the injector well. 


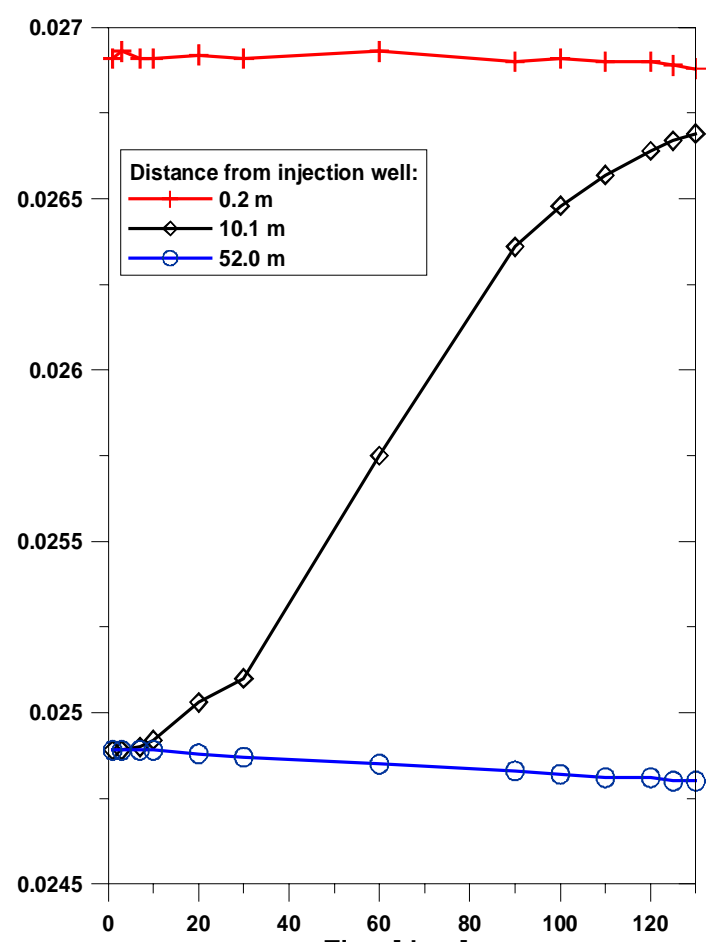

(a)

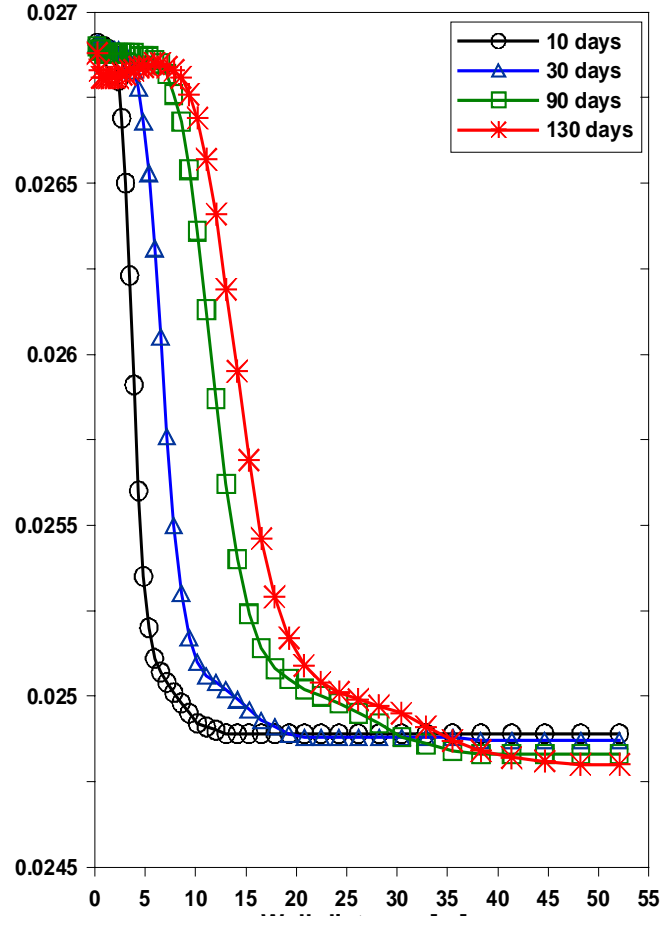

(b)

Fig. 15-Numerical simulation of the concentration of the aqueous species $\mathrm{Ca}^{2+}$ at distances of $0.2 \mathrm{~m}, 10.1 \mathrm{~m}$ and $52.0 \mathrm{~m}$ from the injector well (Fig. 15a). $\mathrm{Ca}^{2+}$ concentrations at different times $(10,30,90,130$ days) to a distance of $50 \mathrm{~m}$ from the injector well (Fig. 15b).

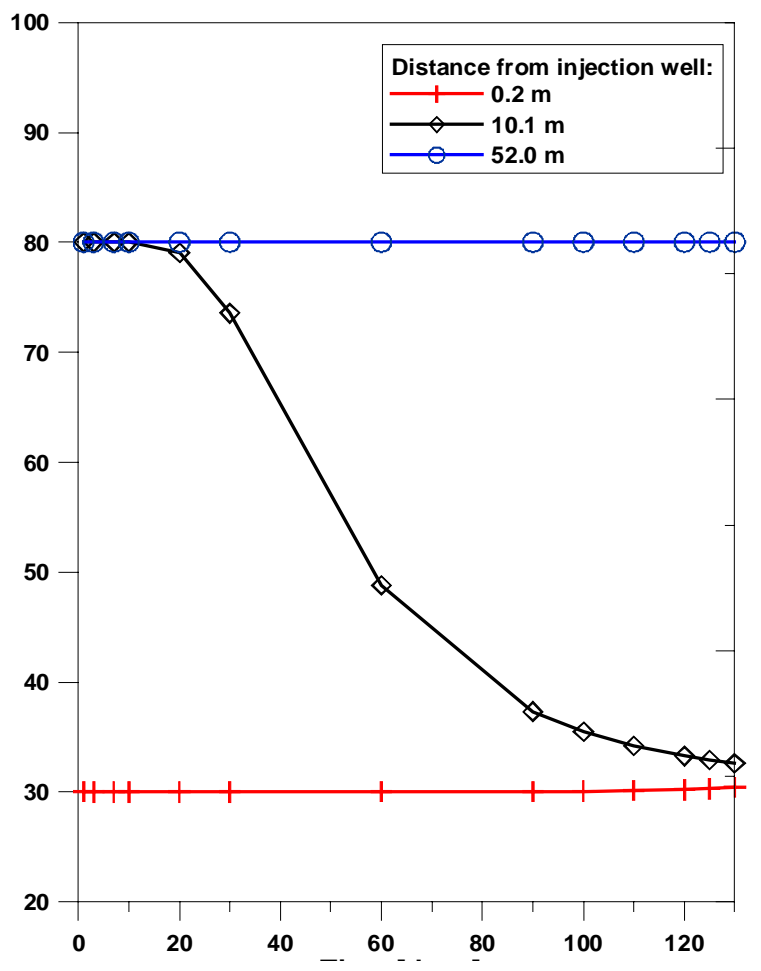

Fig. 16-Numerical simulation of the temperature distribution of the injector interval at distances of $0.2,10.1$ and $52.0 \mathrm{~m}$ from the injector well during 130 days of injection.

\section{Case 2 (Optimistic case):}

In the optimum case of abundant artificial fracturing within the injection interval, an average horizontal permeability of $500 \mathrm{mD}$ is applied as input data for initial reservoir conditions. In comparison to the previous 
case, the increase from $50 \mathrm{mD}$ to $500 \mathrm{mD}$ does not significantly affect the chemical pattern of water-rock interaction, because the same injection rates were applied, but causes a slightly lower velocity for well plugging. The rise of reservoir pressure from 240 bar to 300 bar is extended from 130 days (Case 1) to 145 days (Case 2).

\section{Case 3 (Worst case):}

In order to simulate a potential lower permeability scenario, an initial value of $5 \mathrm{mD}$ was selected for $\mathrm{K}_{\mathrm{L}}$ and the initial $\phi_{\text {eff }}$ value was reduced from $16.3 \%$ to $12.0 \%$. As a general result, less favorable hydraulic conditions accelerate the process of scale deposition. Within a period of 30 days, reservoir pressure increases from 240 bar to 347.4 bar due to the reduction of pore space from $12.0 \%$ to $11.46 \%$ close to the injection well (Fig. 17). Continuing the simulation up to 60 days, pressure is rising to unrealistic values (severe plugging) above 700 bar. Similar to the previous cases, the permeability is reduced (from $5 \mathrm{mD}$ to $1.5 \mathrm{mD}$ ) by the precipitation of calcite and coelestine. The affected zone is limited to a radial distance of less than 10 $\mathrm{m}$ around the injection well.

It can be concluded that the injection of untreated formation water into the oil reservoir will cause plugging of the injection interval. Variations of the primary permeability and porosity alter the time scale of plugging. Assuming a low permeability of $5 \mathrm{mD}$ (Case 3), the reservoir pressure rises to 300 bar within 24 hours of injection. Complete plugging of the reservoir by mechanical obstruction and mineral precipitation is predicted to occur after 30 days (Table 9). Larger $\mathrm{K}_{\mathrm{L}}$ values of $50 \mathrm{mD}$ (Case 1) or $500 \mathrm{mD}$ (Case 2) can extend the time period for formation plugging to between 130 to 150 days.

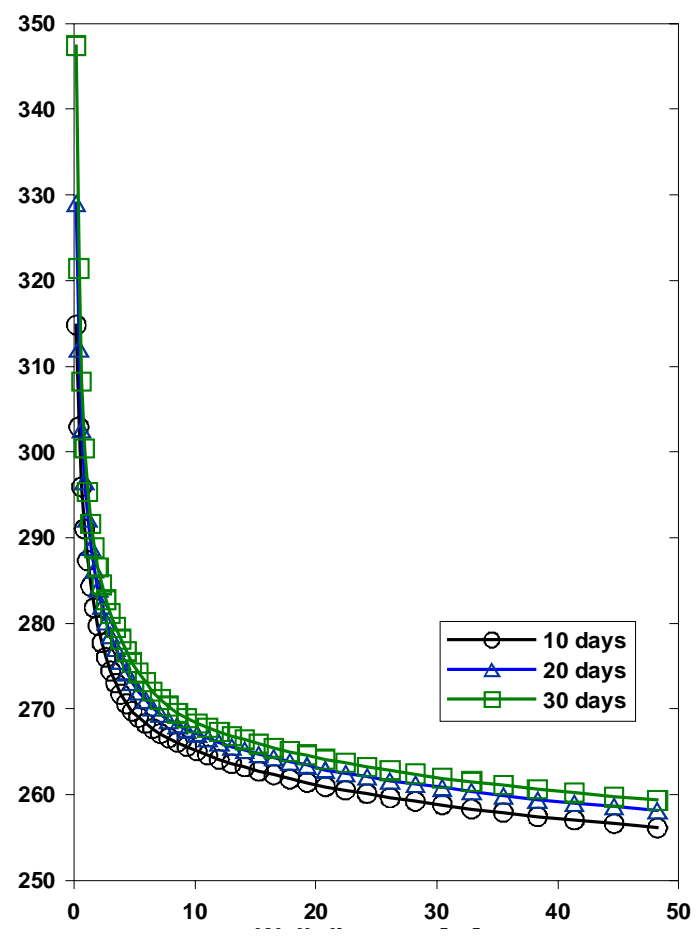

Fig. 17-Pressure profiles during the injection of reservoir water into a low-permeable reservoir at different times $(10,20,30$ days) to $50 \mathrm{~m}$ from the injection well. 
TABLE 9-COMPARISON OF SIMULATION RESULTS FOR DIFFERENT CASES (DISTANCE: 0.2 M FROM INJECTION WELL).

\begin{tabular}{l|l|l|l}
\hline Parameter & $\begin{array}{l}\text { Case 1: } \\
\text { Reference case }\end{array}$ & $\begin{array}{l}\text { Case 2: } \\
\text { Optimistic case }\end{array}$ & $\begin{array}{l}\text { Case 3: } \\
\text { Worst case }\end{array}$ \\
\hline Initial $\mathrm{K}_{\mathrm{L}}[\mathrm{mD}]$ & 50.0 & 500.0 & 5.0 \\
Initial $\Phi_{\text {eff }}[\%]$ & 16.3 & 16.3 & 12.0 \\
\hline 1. Pressure rise from 240 bar close to 300 bar: & 130 & 145 & 1 \\
Time period [days] & 0.93 & 1.01 & 4.78 \\
Final $\mathrm{K}_{\mathrm{L}}[\mathrm{mD}]$ & 13.50 & 13.19 & 11.97 \\
Final $\phi_{\text {eff }}[\%]$ & 296.2 & 265.0 & 293.9 \\
Final pressure [bar] & 2.24 & 2.47 & 0.02 \\
Calcite precipitation (rock vol. \%] & & & \\
2. Complete clogging of injection well: & 145 & 150 & 30 \\
Time period [days] & 0.09 & 1.04 & 1.50 \\
Final $\mathrm{K}_{\mathrm{L}}[\mathrm{mD}$ ] & 13.18 & 13.09 & 11.46 \\
Final $\phi_{\text {eff }}[\%]$ & 497.9 & 418.9 & 347.4 \\
Final pressure [bar] & 2.48 & 2.55 & 0.43 \\
Calcite precipitation (rock vol. \%] & & \\
\hline
\end{tabular}

Step-like injection rates and intermediate fall-off stages during the waterflooding pilot project in well AF847 (see Introduction) make the direct comparison with present simulation results difficult. Selecting the injection stage 3 with a similar injection rate for AF-847 (Q=960 BPD, with a time step from 378 h to $547 \mathrm{~h}$ in Fig. 2) as applied for simulation (Q=821 BPD), the resulting net pressure increase of 45.6 bar in 7 days (from 95.3 to 140.9 bar, Fig. 2) lies within a comparable range as the simulated case studies, with $\Delta \mathrm{P}$ of 2 bar, 15 bar and 110 bar for the optimistic case 2, for reference case 1 (Fig. 12a), and the pessimistic case 3, respectively.

\section{Injection of treated water into the oil reservoir}

Results from laboratory flow experiments, mineralogical-chemical studies of reservoir water and well cores, as well as numerical simulations, indicate that oversaturation of several aqueous species (especially $\mathrm{Ca}^{2+}, \mathrm{Mg}^{2+}, \mathrm{HCO}_{3}{ }^{-}$, and $\mathrm{SO}_{4}{ }^{2}$ ) causes precipitation of secondary minerals, such as calcite [ $\left.\mathrm{CaCO}_{3}\right]$, coelestine $\left[\mathrm{SrSO}_{4}\right]$, ankerite $\left[\mathrm{Ca}(\mathrm{Fe}, \mathrm{Mg}, \mathrm{Mn}) \mathrm{C}_{2} \mathrm{O}_{6}\right]$ and dolomite $\left[\mathrm{Ca} \mathrm{Mg}\left(\mathrm{CO}_{3}\right)_{2}\right]$. Suspended solids (SST, turbidity), total hardness $\left(\mathrm{Ca}^{2+}, \mathrm{Mg}^{2+}\right)$ and presence of bicarbonates, sulfur, silica, barium, iron, and organic material (grease and oil, chemical oxygen demand, total organic carbon, color) may cause mineral precipitation and pore clogging during the injection process. The treatment technology for purifying reservoir water was focused on the removal of the mentioned contaminants by softening with lime and $\mathrm{Na}_{2} \mathrm{CO}_{3}$, oxidation with $\mathrm{H}_{2} \mathrm{O}_{2}$, acidizing to remove carbonate solutes, filtration with sand columns and adsorption with activated carbon $^{14}$.

In order to corroborate the efficiency of the treatment design, numerical simulations were performed with treated water, derived from laboratory experiments with the designed treatment sequence. Petrophysical and mineralogical input parameters were maintained from Case 1 with the modified chemical composition of reservoir water (Table 10).

The applied treatment process improves considerably the injectivity of the well and the flow capacity of the reservoir. Injecting at a rate of $1.51 \mathrm{~kg} / \mathrm{s}$ into a 50 m-thick layer, the porosity and permeability of the host rock increases from $16.3 \%$ and $50 \mathrm{mD}$ to maximum values of $19.7 \%$ and $210.9 \mathrm{mD}$, respectively, within 180 days (Fig. 18). The increase of pore space promotes stable pressure conditions in the reservoir, which rise only slightly from 240.0 bar to 259.7 bar close to the well screen (Fig. 19). 
TABLE 10-HYDROCHEMICAL COMPOSITION OF TREATED RESERVOIR WATER (FROM LABORATORY EXPERIMENTS) FOR INJECTION INTO THE AGUA FRÍA RESERVOIR.

\begin{tabular}{cc|lc}
\hline $\begin{array}{l}\text { Aqueous } \\
\text { species }\end{array}$ & Conc. [mol/kg] & $\begin{array}{l}\text { Aqueous } \\
\text { species }\end{array}$ & Conc. [mol/kg] \\
\hline $\mathrm{H}^{+}$ & $3.4674 \times 10^{-9}$ & $\mathrm{Cl}^{-}$ & $0.5098 \times 10^{0}$ \\
$\mathrm{Ca}^{+2}$ & $4.8154 \times 10^{-4}$ & $\mathrm{O}_{2}(\mathrm{aq})$ & $6.6657 \times 10^{-5}$ \\
$\mathrm{Mg}^{+2}$ & $4.1966 \times 10^{-4}$ & $\mathrm{~F}^{-}$ & $1.0527 \times 10^{-4}$ \\
$\mathrm{Na}^{+}$ & $0.4020 \times 10^{0}$ & $\mathrm{Br}$ & $1.1128 \times 10^{-3}$ \\
$\mathrm{~K}^{+}$ & $8.4760 \times 10^{-3}$ & $\mathrm{I}^{-}$ & $4.8855 \times 10^{-5}$ \\
$\mathrm{Fe}^{2+}$ & $3.4916 \times 10^{-5}$ & $\mathrm{Sr}^{2+}$ & $3.8803 \times 10^{-5}$ \\
$\mathrm{SiO}_{2}(\mathrm{aq})$ & $4.8780 \times 10^{-4}$ & $\mathrm{Ba}$ & $8.0090 \times 10^{-6}$ \\
$\mathrm{HCO}_{3}{ }^{-2}$ & $4.3005 \times 10^{-3}$ & $\mathrm{~B}(\mathrm{OH})_{3}(\mathrm{aq})$ & $2.6457 \times 10^{-3}$ \\
$\mathrm{SO}_{4}{ }^{2-}$ & $1.7198 \times 10^{-3}$ & $\mathrm{Li}$ & $3.0548 \times 10^{-3}$ \\
$\mathrm{AlO}_{2}^{-}$ & $2.657 \times 10^{-12}$ & & \\
\hline
\end{tabular}
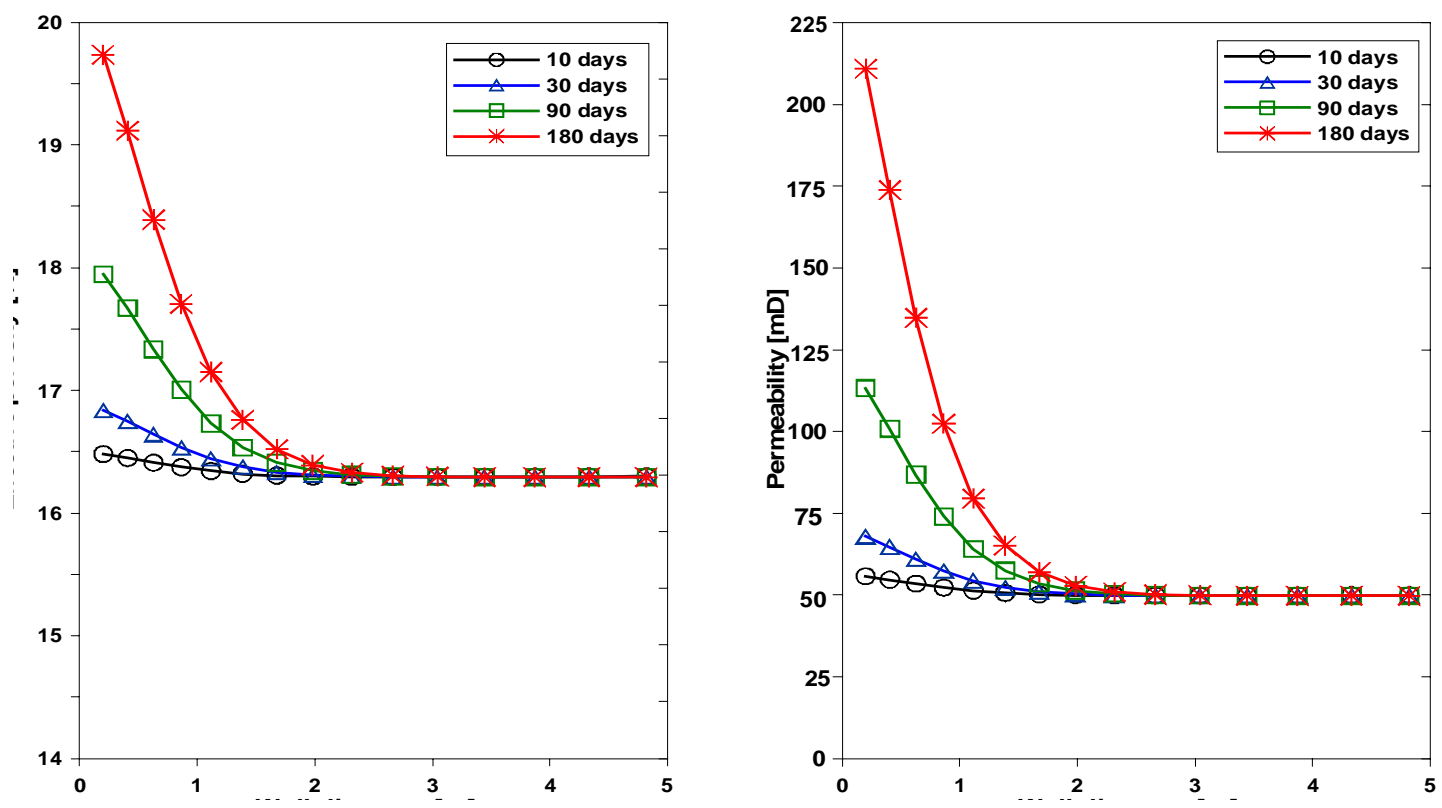

Fig. 18- Injection of treated reservoir water: Numerical simulation of variations in reservoir porosity (left) and permeability (right) at different times $(10,30,90,180$ days) to a distance of $5 \mathrm{~m}$ from the injection well. 


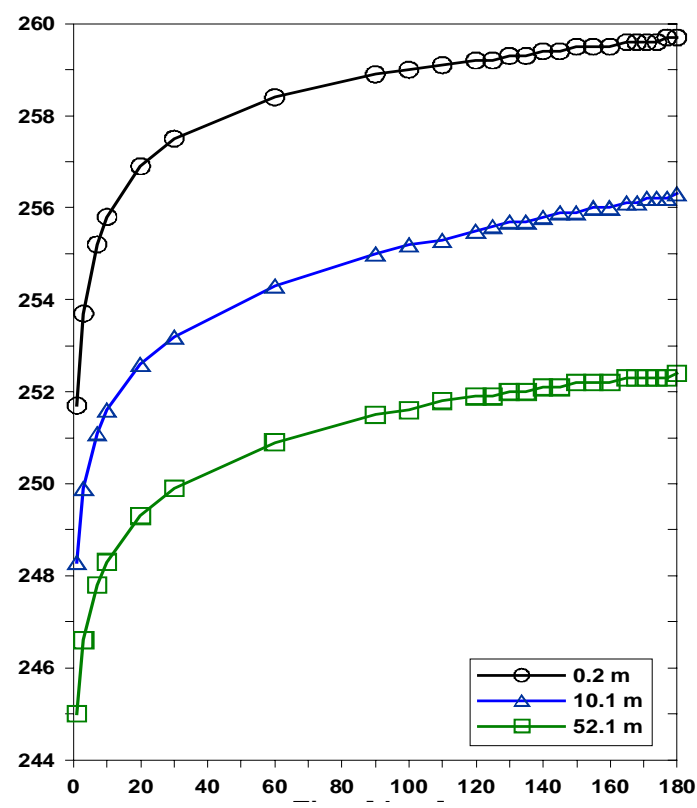

Fig. 19-Injection of treated reservoir water: Numerical simulation of variations in reservoir pressure at distances of $0.2,10.1$ and $52.0 \mathrm{~m}$ from the injection well.

The simulation results indicate that the main reason for stable hydraulic conditions of the reservoir is the lack of precipitation of secondary minerals. In contrast, under-saturated conditions of the injected fluid cause the dissolution of calcite (Fig. 20) and ankerite minerals from the host formation. In general, using treated water that performed well in the laboratory flow experiments was found to avoid excessive precipitation, and allowed injection to proceed.

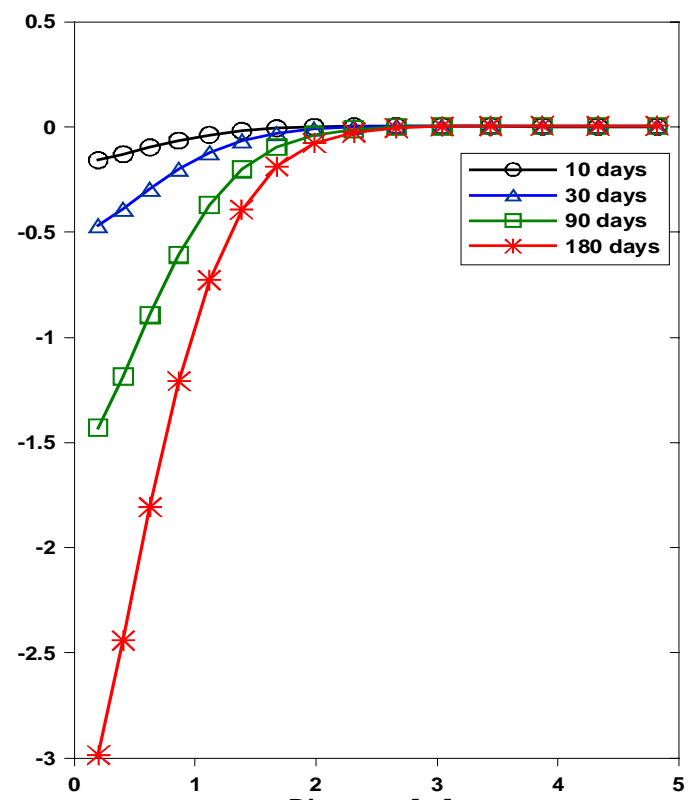

Fig. 20- Injection of treated reservoir water: Numerical simulation of the dissolution of calcite at different times (10, 30, 90, 180 days) to a distance of $5 \mathrm{~m}$ from the injection well.

Petrophysical coreflood experiments with treated reservoir water and identical core material used for the untreated coreflood case (Chapter 2.1. "Cuerpo 70” from well Coapechaca-595) show a similar decrease in permeability as shown for the untreated water case, as geomechanical effects are dominating flow-through behaviour. On the other hand, chemical analyses of the inlet and outlet water samples represent best 
indicators for chemically reactive processes during the coreflood experiment. Similar as in the model prediction, $\mathrm{CO}_{3}{ }^{2-}, \mathrm{SO}_{4}{ }^{2-}$ and $\mathrm{Ca}^{2+}$ concentrations are rising from 1,362 to $1,420 \mathrm{mg} / \mathrm{kg}, 75.7$ to $90.0 \mathrm{mg} / \mathrm{kg}$ and 5.3 to $8.7 \mathrm{mg} / \mathrm{kg}$, respectively, due to beginning dissolution processes of carbonate and sulfate minerals. $\mathrm{Ca}^{2+}$ and $\mathrm{SO}_{4}{ }^{2}$ increase their initial concentration by $64 \%$ and $19 \%$, respectively (Fig. 21). Some trace elements, such as $\mathrm{Ba}^{2+}$ and $\mathrm{Si}^{4-}$, were depleted during coreflood experiment by lower solubility conditions, causing their potential precipitation. The chemical composition of treated reservoir water allows equilibrated thermodynamic conditions for the injected fluid with a trend towards an undersaturated state with minor dissolution processes.

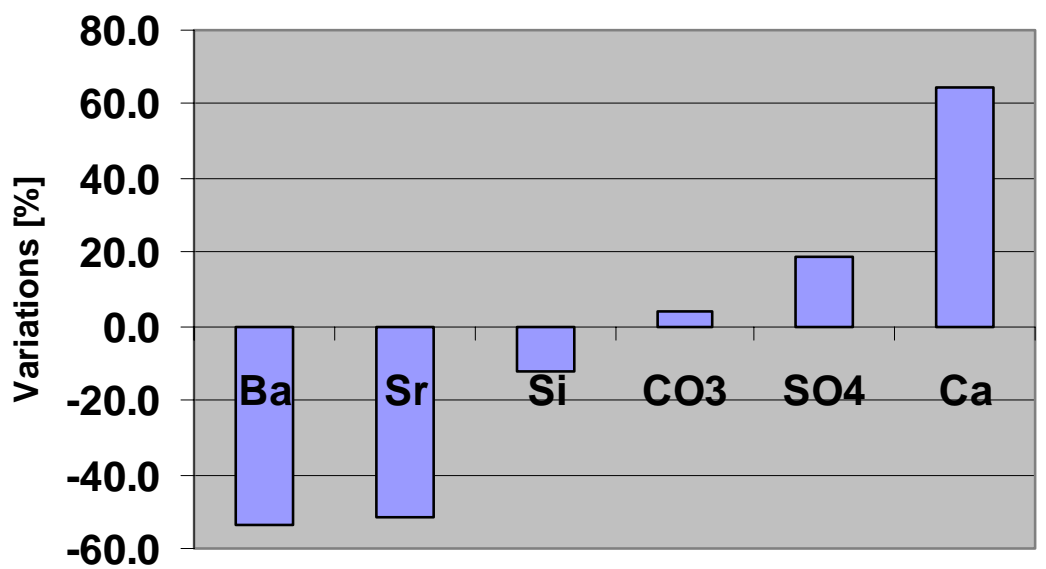

Fig. 21-Petrophysical coreflood experiment with treated reservoir water: Relative variation of the chemical composition between inlet and outlet water sample.

\section{Permeability limitations of the reservoir}

The removal of specific solutes from the reservoir water allows the continuous injection into the Agua Fría reservoir without well plugging by precipitation of secondary minerals, as shown in the previous section. On the other hand, low-permeable conditions could represent a natural limitation for the migration of fluids within the pore space. In the case of the Agua Fría reservoir, petrophysical logs show a natural permeability range between 0.1 and $10.0 \mathrm{mD}$ without considering the possible existence of artificial fracturing. In the hypothetical case of injecting treated water under reduced permeability conditions of $5 \mathrm{mD}$ - in contrast to $50 \mathrm{mD}$ in the previous section - chemical reactions are dominated by physical processes.

Similar to the $50 \mathrm{mD}$ case, calcite and ankerite dissolve during injection, causing increasing permeability (from 5.0 to $22.3 \mathrm{mD}$, Fig. 22) and porosity (from 12.0 to 14.7\%). On the other hand, the pressure rise from 240.0 bar to maximum values of 408.1 bar after 180 days indicates that, although a significant increase of porosity and permeability occurs from dissolution processes, the planned injection rate $(1.51 \mathrm{~kg} / \mathrm{s}$ within a 50 $\mathrm{m}$ thick layer) cannot be maintained for permeability as low as $5 \mathrm{mD}$ (Fig. 22).

In the present case, mineral dissolution does not represent the determining factor to define the potential for water injection; instead, low permeability of the reservoir is the limiting parameter for the capacity of the injection well. Treatment of the fluids will prevent scaling and formation plugging during the injection process, but low permeability conditions can be a natural limitation for injection rates. 

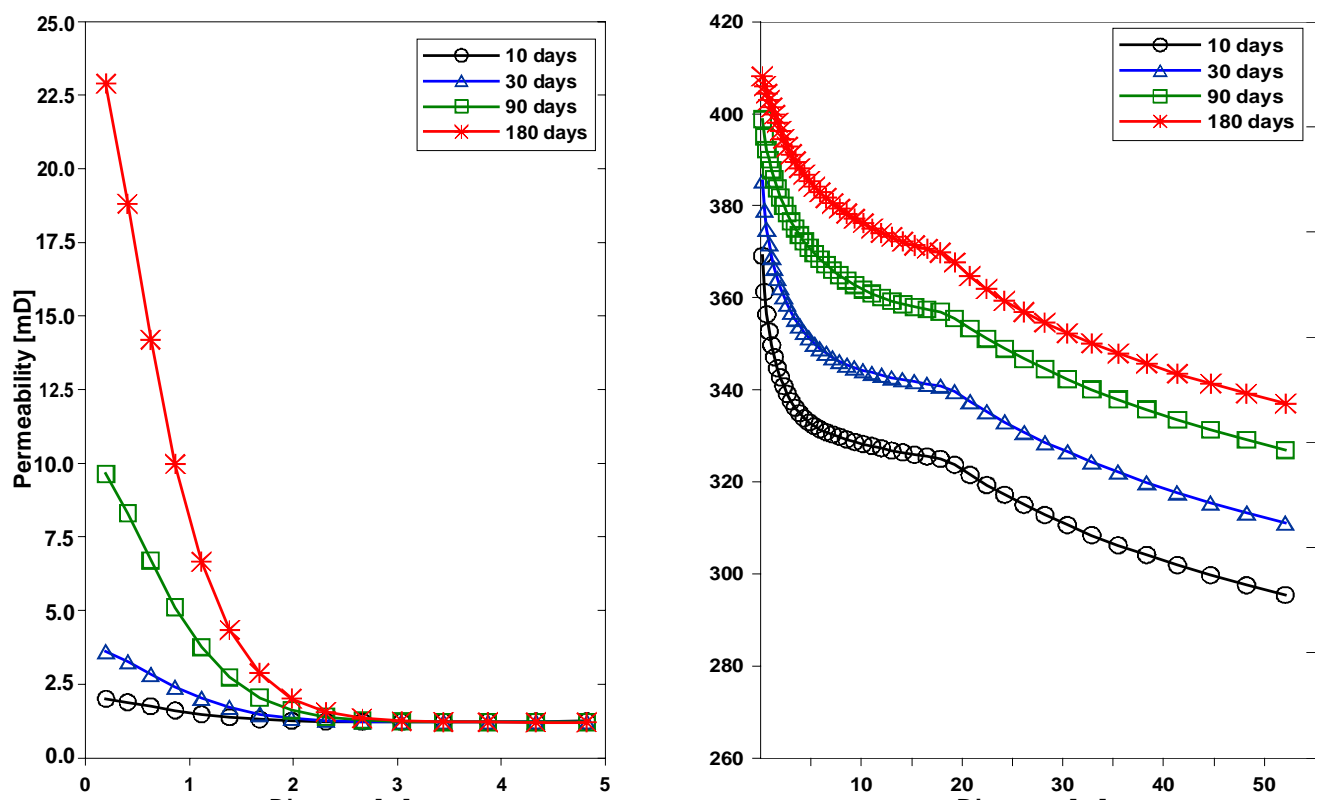

Fig. 22- Injection of treated reservoir water under reduced permeability conditions: Numerical simulation of variations in reservoir permeability (left) and pressure (right) at different times (10, 30, 90, 180 days).

\section{Discussion}

Water injection into the Chicontepec reservoir of the Agua Fría field would cause progressive plugging if untreated reservoir water were used, due to precipitation of secondary minerals, especially calcite and coelestine. Fast chemical reactions of calcite restrict the plugging to a limited radial distance of $2.5 \mathrm{~m}$ around the injection well. The injection of tepid fluids causes the gradual radial cooling of the reservoir, whereby increasing calcite solubility induces rising $\mathrm{HCO}_{3}{ }^{-}$and $\mathrm{Ca}^{2+}$ concentrations. Depending on the selected input value for the primary permeability of the host formation, a time period between 30 and 150 days is postulated as maximum life-time for the injection wells, before plugging by scaling would cause unacceptable pressure rise. The injectivity loss after five months of waterflooding of the well AF-847, performed as a pilot project in 1999, is consistent with the simulated time period for formation plugging. The precipitation of carbonate minerals is also reconfirmed by the successful partial restoration of the injectivity of the AF-847 well by acidizing with $\mathrm{HCl}$, as well as by observed decreasing $\mathrm{HCO}_{3}{ }^{-}$and $\mathrm{Ca}^{2+}$ concentrations during laboratory flow experiments. Treatment of the reservoir water to remove selected aqueous species, especially $\mathrm{Ca}^{2+}, \mathrm{Sr}^{2+}, \mathrm{HCO}_{3}{ }^{-}$and $\mathrm{SO}_{4}{ }^{2-}$, will considerably enhance the injectivity of the injection well. Additionally, under-saturated conditions of treated water will improve permeability characteristics of the reservoir by the dissolution of carbonate minerals.

Although the proposed treatment system will avoid plugging of the injection interval by chemical processes, the simulation results show that existence of less favorable permeability conditions could limit the hydraulic capacity of the injection wells. While an injection well with $K_{L}$ values between 50 and 500 millidarcies allows the injection of 821 barrels per day into a $50 \mathrm{~m}$ thick layer, the simulated pessimistic case with a low natural permeability of five millidarcies could not accommodate such an injection rate, even if porosity and permeability near the well are being enhanced due to dissolution of carbonate minerals. In order to determine the injectivity of the selected wells, pressure transient tests or step rate tests should be performed prior to initiating waterflooding on a large scale.

\section{Conclusions}

- The numerical simulation of chemical processes during the injection of reservoir water at the Agua Fria petroleum reservoir confirms a potential risk for formation plugging due to the precipitation of carbonate minerals, mainly calcite $\left(\mathrm{CaCO}_{3}\right)$ and coelestine $\left(\mathrm{SrSO}_{4}\right)$, also indicated by the short life-time of well AF-847 during a pilot project for field injection.

- Coreflood experiments with representative cores show a faster permeability decrease than for the modeled scenarios, as clay-abundant cores are additionally affected by clay swelling effects. A 
quantitative measure of the extent of chemical reactivity during waterflooding is given by the analytical comparison between inlet and outlet composition of experimental fluids.

- For both petrophysical experiments and reactive modeling, a decrease of the initial $\mathrm{Ca}^{2+}, \mathrm{HCO}_{3}{ }^{-}$and $\mathrm{SO}_{4}{ }^{2-}$ concentrations in the aqueous phase supports the occurence of precipitation processes during the injection.

- Field injection tests, laboratory coreflood experiments (including mineralogical and aqueous solute analysis) and reactive modeling represent a successful methological combination to evaluate the injectivity of water into oil reservoirs.

- $\quad$ The modeling of the lab experiments can be further improved by adjusting primary mineral composition and reaction kinetics of some minerals. The reactive transport modeling method presented here can give a detailed view of the dynamical interplay between coupled hydrologic and chemical processes, albeit in an approximate fashion. A critical evaluation of modeling results can provide useful insight into the long-term water-flooding performance.

\section{Acknowledgment}

Peter Birkle acknowledges specific contract 414105890 (No. SAP 4141058900) between the Instituto de Investigaciones Eléctricas (IIE) and Petróleos Mexicanos (PEMEX, Subdirección Region Norte), and expresses gratitude for technical and logistical support from the Coordinación de Diseño de Explotación area at the Activo Integral Poza Rica - Altamira oilfield. Thanks to the PEMEX administration for the permission to publish the presented data. Karsten Pruess and Tianfu Xu acknowledge contract No. DE-AC0205CH11231 between the Regents of the University of California and the U.S. Department of Energy.

\section{References}

1. Williams, P.: “Mexico,” Oil and Gas Investor (July 2003) 26.

2. García Esparza, N.T., Mendoza Ruíz, J., Mengual, J.-F., and Sosa Cerón, A.: "Well construction and field development in Mexico," Oilfield Review (Spring 2004) 48.

3. American Petroleum Institute: “API Recommended Practices for Core-Analysis,” API document RP 40, $2^{\text {nd }}$ Edition (Feb. 1998).

4. Pruess, K., Oldenburg, C., and Moridis, G.: “TOUGH2 User's Guide, Version 2.0,” Lawrence Berkeley National Laboratory Report LBNL-43134, Berkeley, California (Nov. 1999).

5. Narasimhan, T. N., and Witherspoon, P. A.: "An integrated finite difference method for analyzing fluid flow in porous media," Water Resour. Res. (1976), vol. 12, 57.

6. Xu, T., and Pruess, K.: “Modeling multiphase fluid flow and reactive geochemical transport in variably saturated fractured rocks: 1. Methodology,” Am. J. Sci. (2001), vol. 301, 16.

7. Xu, T., Sonnenthal, E.L., Spycher, N., and Pruess, K.: “TOUGHREACT: A simulation program for non-isothermal multiphase reactive geochemical transport in variably saturated geologic media," Computer \& Geoscience (2006), vol. 32, 145.

8. Vaughan, P.J.: “Analysis of permeability reduction during flow of heated, aqueous fluid through Westerly Granite,” In: C.F. Tsang (ed.) “Coupled processes associated with nuclear waste repositories”, Academic Press, N.Y. (1987) 529.

9. Pape, H., Clauser, C., and Iffland, J.: “Permeability prediction based on fracture pore-space geometry,” Geophysics (1999), vol. 64(5), 1447.

10. Verma, A., and Pruess, K.: “Thermohydrologic conditions and silica redistribution near high-level nuclear wastes emplaced in saturated geological formations,”.J. of Geophys. Res. (1988), vol. 93, No. B2, 1159.

11. Scheidegger, A. E.: "The Physics of Flow Through Porous Media,“ University of Toronto Press, Toronto and Buffalo, Third Edition, 1974.

12. Hajpál, M., and Török, Á.: “Mineralogical and color changes of quartz sandstones by heat,” Environmental Geology (2004), vol. 46(3-4), 311.

13. Tixier, M.P.: “Evaluation of permeability from electric-log resistivity gradients,” Oil \& Gas J. (June 1949) 113.

14. Birkle, P., Mijaylova, N. P., Pruess, K., Xu, T., Contreras, E.L., and García, P.M.: "Definición del proceso de tratamiento requerido para el agua congénita de la Central de Almacenamiento y Bombeo (CAB) Poza Rica," Final report IIE11/12901/I03/F, Contract No. 414105890, Instituto de Investigaciones Eléctricas, Cuernavaca, Morelos, Mexico (April 2006) 1002 pp.

15. Kishi, T.: “EQ3/6 Software test and verification report 9/94,” UCRL-ID-119140, Lawrence Livermore National Laboratory, CA, USA (Feb. 1996) 42 pp.

16. Xu, T., Ontoy, Y., Molling, P., Spycher, N., Parini, M., Pruess, K., 2004. Reactive transport modeling of injection well scaling and acidizing at Tiwi Field, Philippines. Geothermics, 33, 477-491. 